EISSN: 2706 -7947 ISSN: 2077- 4613

DOI: 10.36632/mejas/2021.11.2.43

Journal homepage: www.curresweb.com

Pages: 531-569

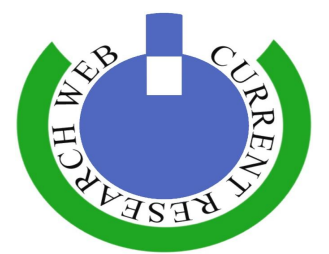

\title{
Zinc in the Soil and Its Importance for the Plants and Human Health. An integrated review
}

\author{
El-Sayed A.A. ${ }^{1}$, El-Dahshouri M.F. ${ }^{1}$, El Masry M.F.A. ${ }^{1}$, Hassan H.S.A. ${ }^{2}$ and Darwish \\ M.A. ${ }^{1}$
}

${ }^{1}$ Fertilization Technology Dept. and ${ }^{2}$ Pomology Dept., National Research Centre, 33 El Buhouth St., 12622 Dokki, Giza, Egypt

Received: 15 March $2021 \quad$ Accepted: 10 June $2021 \quad$ Published: 20 June 2021

\begin{abstract}
Zinc as an essential element plays an important role in the balanced integrated nutrition of plants. It is an important microelement for improving the yield and quality of agricultural products, and hence improves animals and human health. Zinc has special physiological functions in all living organisms, such as maintaining the structural and functional integrity of biological membranes, facilitating protein synthesis, gene expression, enzyme synthesis, energy production and the Krebs cycle. Zn deficiency is a universal problem of great importance for agriculture and human health, as a lack of zinc element in the soils reduces crop productivity and qualities, because of the imbalance caused in many physiological functions dependent on zinc and are unable to function normally. The soil factors viz., $\mathrm{pH}$, organic matter, clay percentage, calcium carbonate content are consider as the most important factors that affecting the availability of zinc to plants. Zinc availability in the soils is greatly affected by their total zinc content, organic matter contents, soil moisture status, microbial activity in the rhizosphere, redox conditions, and concentrations of other macro and microelements, especially copper, phosphorus and nitrogen. In arid and semi-arid regions, calcareous soils (rich in calcium carbonate) are widespread, which is distinguished by low zinc availability and consequently low zinc availability and uptake by plants. As zinc is an active element in the biochemical processes, and there are chemical and biological interactions between $\mathrm{Zn}$ and some other elements such as phosphorus, iron, copper and nitrogen. Zinc deficiency considered as the most widespread micro nutrient deficiencies in crops and pastures worldwide, which affecting plant growth and causes large losses in crop production and quality. $\mathrm{Zn}$ visible deficiency symptoms could be one or more of the following symptoms: interveinal chlorosis, necrotic, bronzing, rosetting of leaves, stunting of plants, dwarf leaves and malformed leaves. Around half of the world's cereal crops are cultivated on zinc-deficient soils; as a result, zinc deficiency in animals and humans is a widespread problem. In many parts of the world zinc deficiency in the early stages of a human's life impaired physical growth, neuro development, brain function, memory, and learning ability. Severe zinc deficiency in human's is characterized by stunting, lack of normal sexual development, impaired immune response, skin disorders, hair loss, loss of appetite, and weak body muscles. Recently, elemental zinc is considered as potential supportive treatment in the therapy of COVD-19 infection. The recommended dietary allowances (RDAs) for zinc as recommended by the Dietary Office of the National Institutes of Health are: 2-3 mg per day for infants, $5 \mathrm{mg}$ per day for children, 8-11 mg per day for adolescents and adults, and 11-13 $\mathrm{mg}$ per day for pregnant and lactating women.
\end{abstract}

Keywords: Zinc; Soils; Bioavailability; Balance. Deficiency; Plant Nutrition; Human health.

\section{Introduction}

Zinc $(\mathrm{Zn})$ deficiency is a vital problem in some areas for both plants and human, particularly in developing countries, which mainly dependent on cereal crops to fulfill their need for food and nearly

Corresponding Author: El-Sayed A.A., Fertilization Technology Dept., National Research Centre, 33 El Buhouth St., 12622 Dokki, Giza, Egypt. E-mail: adelabdelkhalik@hotmail.com 
50 percent of global population is suffering from Zn-deficiency (Alloway, 2008; Cakmak, 2004 $\& 2008)$. The concern about the problem of zinc deficiency is increasing day by day, as zinc plays many vital roles in the biological functions of both humans and plants, as it is one of the essential microelements required for optimal growth and productivity. (Hortz and Brown, 2004; Fraga, 2005; Alloway, 2008; Noulas et al., 2018).

Zinc belongs to the group of eight essential trace elements (manganese, copper, boron, iron, zinc, chlorine, molybdenum, and nickel), which required for proper plant growth and productivity, however, zinc deficiency in agricultural soils has been recognized as a global problem, especially in calcareous soil in arid and semi-arid regions of the world (Bityutski et al., 2017; Noulas et al., 2018; Chen et al., 2019). In such soils, the total zinc content may be relatively high; but the main problem is the low availability of zinc due to the low content of organic matter and the high content of calcium carbonate (Rengel, 2015; Bityutski et al., 2017; Kumari et al., 2018).

Zinc $(\mathrm{Zn})$ plays a fundamental role in many biological processes in plant; as required in various enzymatic reactions, metabolic processes, and oxidation-reduction reactions, and is an essential trace element for proper normal and healthy plant growth and yielding. It is also required for normal health of animals and humans (Noulas et al., 2018). Thus, zinc deficiency stress in plants, normally due to low-zinc bioavailability in soil, causes significant decreases in the productivity and nutritional quality of food and has negative effects on human beings health. Zinc is required as a structural component of a large number of proteins, as it is a cofactor in metaloenzymes (de Figueiredo et al., 2007) involved in protein synthesis and energy production, as well as in the maintenance of biomembrane structural integrity and production of IAA (Indole Acetic Acid), that is responsible for plant growth (leaf elongation) (Hanch \& Mendel, 2009; Marschner, 2011).

Zn-deficiency can also help in increasing the level of reactive oxygen species (ROS) that interfere with the mechanisms of cellular detoxification. This can by reducing the activity of anti-oxidative enzymes such as $\mathrm{Cu} / \mathrm{Zn}$ superoxide dismutase and carbonic anhydrase (Cakmak, 2000; Hacisalihoglu and Kochian, 2003), resulting in reduction in growth and crop production. It is also involved in several biological reactions of cellular metabolism, including biological processes, such as antioxidant defense, protein synthesis, carbohydrate metabolism, auxin metabolism, and stability of genetic materials (Clemens et al., 1999; Broadley et al., 2007).

Zinc dynamics in soil-plant systems have important economic and environmental impacts, as zinc is an essential element for the growth and reproduction of all living organisms (Frassinetti et al., 2006). In the case of low zinc availability in the soil, the growing plants will suffer from some physiological disturbances due to the failure of the metabolic processes in which zinc plays a key role. Zinc is known to be one of the essential elements for feeding plants however, it is only required in low concentrations, which makes it act as an essential micronutrient. Zn-concentration between 30 and 100 $\mu \mathrm{g} g-1 \mathrm{DW}$ is sufficient to provide plants with their needs from this vital element, whereas zinc toxicity symptoms are observed in concentrations above $300 \mu \mathrm{g} g-1 \mathrm{DW}$; for plant species that are not adapted to high-zinc exposure (Van de Mortel et al., 2006; Marschner, 2011). However, high accumulation of zinc in plant can be harmful (Szatanik-Kloc et al., 2009). Therefore, for optimal plant growth, plants need close control over zinc balance and always be within the limits of adequacy (Marschner, 2011).

The growth and yield of grains of both wheat and barley significantly decrease when cultivated in zinc deficient soils (Graham et al., 1999; McDonald et al., 2001). The occurrence of zinc deficiency in humans and animals in certain geographical areas, especially in developing countries, is often closely related to the deficiency of this element in the soil, especially when cereals-based foods are the most important sources of calories local population. Soil zinc deficiency may cause a significant decrease in the yield and quality of many crops. The cultivation of food crops in zinc deficient soils is a major problem, which leads to low yields, low zinc content in food, low income for farmers, and discourages them from investing (Erenoglu et al., 2010). Maintaining an adequate concentration of zinc in rice and wheat grains is important for more than two-thirds of the world's population, especially in developing countries, where rice and wheat are the mainstay of their diet, and zinc can be supplemented in food from sources rich in zinc such as seafood, meat and, leafy vegetables and legumes. (Chen et al., 2000; Anderson et al., 2001; Simon and Taylor, 2001).

Zinc deficiency in the soil reduces the zinc content in the edible parts of the staple food crops and reduces their nutritional value (Welsh \& Graham, 2004). For example, growing wheat (Triticum aestivum, L.) on zinc deficient soil in Turkey resulted in reduction in the grains $\mathrm{Zn}$-content by 
approximately $50 \%$ lower compared to wheat grown with adequate zinc supply (Cakmak, and Hoffland, 2012). Therefore, a diet consisting of a high proportion of cereal-based and legumes foods, which contain low $\mathrm{Zn}$, is considered as one of the major reasons for the widespread occurrence of $\mathrm{Zn}$ deficiency in humans, especially in developing countries (Saxena et al., 1993; Singh, 1993; Ganeshmurthy et al., 2006; Biesalski, 2016). Soil nutrients content and management affect crop productivity and nutrients concentration in plant edible parts. Thus, soil nutrients status has great implications on human and animals health. Globally, nearly one third of arable land is deficient in micronutrients, particularly zinc (Zn) (Cakmak et al., 2017), which leads to underproduction and low nutritional value of cultivated crops, and this ultimately negatively effects on animals and human nutrition (Cakmak 2008; Goudia \& Hash 2015). The extent of $\mathrm{Zn}$ deficiency in humans has been estimated by considering the absorbable $\mathrm{Zn}$ content of the national food supply (Wessells and Brown, 2012). Most of the regions in the world with high incidence of $\mathrm{Zn}$ deficiency in humans, found in South and Middle East Asia, Africa and various Latin American countries, where soils have low Znavailability (Figure 1).

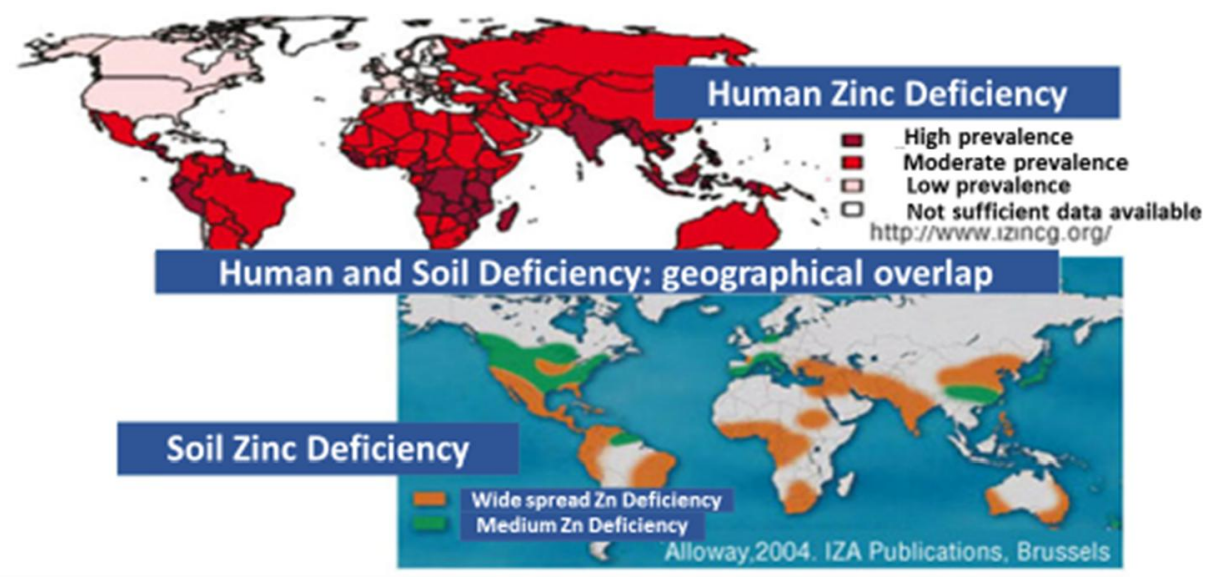

Figure 1: Overlap Between Geographical Regions with Soil and Human Deficiency Source: Cakmak, 2011.

The problem of Zn-deficiency is most common in of arid and semi-arid soils, due to (i) high levels of soil-pH and $\mathrm{CaCO}_{3}$, (ii) low organic matter content (percentage) (Cakmak, 2008; Gonçalves Junior et al., 2010), (iii) in sandy texture soils, (iv) when high analysis NPK fertilizers are used, (v) enhanced Zn-removal by high yielding varieties and (vi) redox changes in flooded soils (Tandon, 1995; Cakmak et al., 1998). However, low solubility of $\mathrm{Zn}$ in soils, rather than low total amount, is the major reason for the widespread occurrence of Zn-deficiency problem in crop plants (Cakmak, 2008). It is very difficult to maintain the optimal amount of bioavailable zinc in the soils because it is mainly from non dissolved compounds with either phosphates, carbonates, sulfides or iron and manganese hydroxides (Kabata-Pendias, 2010). In contrast, free zinc ions and consequently bioavailable Zn, are most common in acidic soils, and highly mobile, and can easily leached from soil (Yun and Yu, 2015). This will limits availability and zinc uptake by plants, resulting in significant decreases in both productivity and nutritional value of food leading to $\mathrm{Zn}$-deficiency in human, which affects more than two billion people (De-Regil et al., 2013; Bailey et al., 2015; FAO, 2015). Approximately one-third of the world's population (two billion people), suffers Zn-deficiency, with prevalence rates ranging from 4 to $73 \%$ in various regions (WHO, 2002).

This paper aims to review and discuss aspects related to the role and dynamics of zinc in the agricultural biological system of soil, water, plants and humans: from the origins of zinc in soil and water to the distribution of zinc deficiency in the soil and the factors that affect its availability. For plants, improving understanding of the different relationships between factors affecting the content, behavior and availability of zinc in the soil and its important role in the growth and productivity of different crops improving their nutritional value and their relationship to human health. 


\section{Zinc in the soils}

Normally, the total $\mathrm{Zn}$ in the soils is ranged between 10 to $300 \mathrm{mg} \mathrm{kg}^{-1}$, with an average of 50 $\mathrm{mg} \mathrm{kg}{ }^{-1}$ (Lindsay, 1972). However, the average of available $\mathrm{Zn}$; as extracted by dithizone does not exceed 1 to $3 \mathrm{mg} \mathrm{kg}^{-1}$. The problem is this very small amount of available- $\mathrm{Zn}$ is due to one or more of adverse factors. The remainder is fixed in the soil in an insoluble or non-exchangeable form and difficult to be available to plant (Stahl and James, 1991). The content of $\mathrm{Zn}$ in unfertilized and uncontaminated soil is related to the chemical composition of its parent materials and the extent of weathering processes (Chesworth, 1991). In the magmatic rocks, it ranges between 40 to $120 \mathrm{mg} \mathrm{kg}^{-1}$, whereas in the sedimentary rocks $\mathrm{Zn}$ contents vary from 80 to $120 \mathrm{mg} \mathrm{kg}^{-1}$ in argillaceous sediments and shales soils, while it ranges only between $15-30 \mathrm{mg} \mathrm{kg}^{-1}$ in sandstones soil and $10-25 \mathrm{mg} \mathrm{kg}^{-1}$ in lime stones and dolomites soils (Kabta-Pendias and Pendias, 2001). Generally, in agricultural soils $\mathrm{Zn}$ is mostly unevenly distributed and its content ranges between 30 and $100 \mathrm{mg} \mathrm{kg}^{-1}$ (Barber, 1995; Mall, 1992), with an overall mean of around $64 \mathrm{mg} \mathrm{kg}^{-1}$ (Kieknes, 1995). In addition, some other; Martens and Smolders, 2013, indicate that total content of contents in unfertilized and Zn-non contaminated soils can vary widely and ranged between 10 to $100 \mathrm{mg} \mathrm{kg}^{-1}$. The mean $\mathrm{Zn}$-contents in worldwide soils was $64 \mathrm{mg} \mathrm{kg}^{-1}$ as shown in Table (1) (Kabta-Pendias and Pendias, 2001). However, soils containing available-Zn less than $0.5 \mathrm{mg} \mathrm{kg}^{-1}$ (DTPA-extractable $\mathrm{Zn}$ ) are considered $\mathrm{Zn}$ deficient for most crops.

Table 1: $\mathrm{Zn}$ content $\left(\mathrm{mg} \mathrm{kg}^{-1}\right)$ in different types of soils.

\begin{tabular}{ll}
\hline Soil type & Abundance $\left(\mathbf{m g ~ k g}^{-1}\right)$ \\
\hline Mean & 64 \\
Light sandy & $31-61$ \\
Medium loamy & $47-61$ \\
Heavy loamy & $35-75$ \\
Calcareous & $50-100$ \\
Organic & $57-100$ \\
\hline
\end{tabular}

Source: Kabta-Pendias and Pendias, (2001)

\section{1- Behavior of zinc in the soils}

In the nature, $\mathrm{Zn}$ is found in the earth's crust as one of the components of rocks or in $\mathrm{Zn}$-rich ores, which are locally formed by natural geological process and are located in soils all over the world. Mertens and Smolders, 2013 stated that, Sphalerite or Wurzite are most economically important ores that contain typically $5-15 \% \mathrm{Zn}$ as zinc sulfates followed by Smithsonite (zinc carbonates) and Hemimorphite (Zn silicates), which contain lesser $\mathrm{Zn}$ minerals. $\mathrm{Zn}$ availability in soil is assessed with chemical extraction procedure (Chen et al., 2019).

The behavior of zinc in the soils is a complex process, as it depends on the dynamics of many heterogeneous soil compounds (Alexakis, 2011), that enables the presence of zinc in several forms, whether soluble or bound to soil particles (Abreu et al., 2007). The availability of $\mathrm{Zn}$ in the soils is strongly dependent on zinc distribution in different soil fractions, as it is exists in three main fractions: (i) water soluble- $\mathrm{Zn}$ (including $\mathrm{Zn}^{2+}$ and soluble organic fractions); (ii) the insoluble $\mathrm{Zn}$ colloidal adsorbed and exchangeable fraction (associated with clay particles, humate compounds and $\mathrm{Al}$ and $\mathrm{Fe}$ hydroxides); and (iii) minerals and complexes zinc (Lindsay, 1979; Barrow, 1993; Alloway, 1995; Barber, 1995). Differences in physical and chemical reactions in the soil can significantly affect the balance between the three organic and inorganic fractions (Tessier et al., 1979; Gismera et al., 2004; Leite et al., 2020). Therefore, the study of different $\mathrm{Zn}$-fractions in the soils is required for better understanding of $\mathrm{Zn}$ availability and the crop need for fertilization (Zahedifar, 2017). Determination of $\mathrm{Zn}$ fractionation in the soils can provide enough information about zinc behavior in soil and crops need for fertilization. Tessier et al., 1979; Rauret et al., 1999; Leite et al., 2020 specified the pools of Zn fractions present in soils as follows: (i) $\mathrm{Zn}$ bound to ion-exchanging sites, and $\mathrm{Zn}$ associated with (ii) carbonates; (iii) organic matter; (iv) Fe and Mn oxides; and (v) a residual fraction. Different $\mathrm{Zn}$ fractions in the soils are greatly differ in in the mode of binding to the soil particles and therefore, in their solubility and availability to plant. The exchangeable-Zn fraction is the most accessible and available form for plants. Availability of Zinc in other fractions (bound to carbonates, organic matter, and Fe and Mn oxides forms), depending upon the soils physicochemical characteristics, and could be considered relatively labile or tightly bound (Sposito et al., 1982; Peppicelli et al., 2018). While, the Zn pools of 
the residual fraction is not mobile and relatively inactive and cannot be soluble or available to plants (Khoshgoftarmanesh et al., 2018). However, different soil zinc fractions are in a dynamic equilibrium with each other, and $\mathrm{Zn}$ distribution between all fractions must be distinguished. Zinc fractions are strongly affected by soil chemicals characteristics, such as soil-pH, and DOC (dissolved organic carbon) (Impa et al., 2012), and CEC (cation exchange capacity) (Khoshgoftarmanesh et al., 2018). Usually, soil-Zn is more available in the soils contain more organic matter (Alloway 2009; Iratkar et al., 2014); due to its large surface negative charge ; measured as CEC) (De Santiago-Martín et al., 2014), and due to the important role of dissolved organic matter in increasing $\mathrm{Zn}$ availability and distribution in the soils (Dehghanian et al., 2018). Generally, zinc availability and distribution in each soil fraction depends on soil organic matter content, $\mathrm{pH}$, and temperature (Tiller et al., 1984), texture, structure, amount and clay minerals type (Spark et al., 1995; Leite et al., 2020), cation exchange, metal oxide fractions (Guadalix and Pardo, 1995; Stahl and James, 1991) and transformations in the source material (Fontes and Alleoni, 2006). The distribution of $\mathrm{Zn}$ between different soil fractions can be determined by soil-specific precipitation, complexation and adsorption reactions. The dominant factor determining soil $\mathrm{Zn}$ distribution is soil is $\mathrm{pH}$ because that $\mathrm{Zn}$ is more readily adsorbed on cation exchange sites at higher $\mathrm{pH}$ and $\mathrm{CaCl}_{2}$ displaces adsorbed $\mathrm{Zn}$ at lower $\mathrm{pH}$. Thus, soluble $\mathrm{Zn}$ and the ratio of $\mathrm{Zn}^{2+}$ to organic Zn-ligand complexes increase at low $\mathrm{pH}$, especially in soils contain low soluble organic matter.

In addition, soil type, moisture, clay types and mineral contents, weathering rates, diffusion and mass flow rates, soil organic matter, and soil biota and plant potential to uptake zinc will also affect $\mathrm{Zn}$ availability and distribution in the soil. It was found that insoluble zinc represent $>90$ percentage of total $\mathrm{Zn}$ in soil and is unavailable for plant uptake. Exchangeable $\mathrm{Zn}$ in the soil typically ranges between 0.1 and $2 \mathrm{mg} \mathrm{Zn} \mathrm{kg}^{-1}$ soil. Concentrations of soluble $\mathrm{Zn}$ in the soil solution are low, typically between $4 \times 10^{-10}$ and $4 \times 10^{-6} \mathrm{~m}$ (Barber, 1995), even in Zn-contaminated soils (Knight et al., 1997). There are several Zn-ligand complexes found in the soil solution that may be not easy to directly measure, and speciation models, based on total dissolved zinc concentrations of and ligands, their stability constants and mineral equilibrium reactions, are often used to inference (Barak \& Helmke, 1993; Zhang et al., 2006). Numerous $\mathrm{Zn}$-ligand complexes can exist in soil solution, which might be difficult to directly measure; $\mathrm{Zn}^{2+}$ typically accounts up to $50 \%$ of the soluble $\mathrm{Zn}$ fraction and is the dominant plant available- $\mathrm{Zn}$ fraction. However, in calcareous soils, $\mathrm{Zn}^{2+}$ may be as low as $10^{-11}: 10^{-9} \mathrm{~m}$ and can negatively affect crop growth and productivity (Hacisalihoglu \& Kochian, 2003). The total $\mathrm{Zn}$ in the soils does not considered a realistic indication of the $\mathrm{Zn}$ availability for plants, as it is easily interacts with some other soil elements, that is varies according to the soil physical or chemical properties and water parameters resulting in a temporary increasing followed by a decreasing in available $\mathrm{Zn}$ for plants (Impa et al.,2012). Many factors affect the availability of zinc in the soil and the ability of plants to absorb it. Under certain circumstances, $\mathrm{Zn}$ solubility and hence its availability for plants decreases due to existence high levels of calcium carbonate, phosphate, metal oxides, high $\mathrm{pH}$ and low content of organic matter and soil moisture (Robson, 1994; Cakmak and Hoffland, 2012).In addition, Zn bioavailability and mobilization in the soils are greatly influenced by some environmental conditions. It is noticed to be associated with the distribution of zinc in soil fractions that can be measured to understand how much this metal influenced by the environment. It is important to distinguish between the total quantities of $\mathrm{Zn}$ in the soils and the amounts that can be transferred into more soluble forms, and becoming bio-available for plants uptake (Begum et al., 2016). In general, the order of presence of zinc forms in the soils remains as follows: exchangeable zinc $<$ organic zinc $<$ zinc carbonates $<$ iron-zinc crystals bound to manganese oxide> residual zinc (Jangir et al., 2019).

\subsection{Zinc deficiency in the Soils}

Zinc deficiency in the soils can be found in most cultivated or cultivable soils in all parts of the world and most crops respond positively to Zn-application (Welch and Graham, 2004). At global level, about one-third of arable soils are deficient in micronutrients, particularly zinc (Zn) (Cakmak et al., 2017), and this eventually affects crop productivity and human nutrition. Approximately $2-3$ billion people all over the world are suffering from micronutrient deficiencies, especially in developing countries (Figure 1), where these affect the health of at least half of the population in such countries (Goudia and Hash 2015). In alkaline soils, which cover at least $30 \%$ of the arable land globally, $\mathrm{Zn}$ availability to plant roots is very low (Chen \& Barak, 1982; Cakmak, 2002; Alloway, 2009).Zinc dominates the list of micronutrients deficient in Sub-Saharan Arable soils (SSA), whose zinc as 
micronutrients is inherited mainly from parent rocks through geochemical and biochemical weathering processes (Kihara et al., 2017). Besides the mineral composition of the parent material, the total amount of zinc present in the soil also depends on the type and severity of climate and many other dominant factors during the soil formation process (Saeed and Fox, 1977). Soils derived from granite and gneiss can be low in total zinc (Krauskopf, 1972). Similarly, total Zn is low in highly leached acid sandy soils such as the ones found in many coastal areas (Alloway, 2008). In addition, quartz in the sandy soils dilutes $\mathrm{Zn}$ concentrations because of it contain is very low amounts of zinc, which ranged from $1.0 \mathrm{mg}$ $\mathrm{kg}^{-1}$ to $<5-8 \mathrm{mg} \mathrm{kg}^{-1}$ (Brehler and Wedepohi, 1978). Meanwhile, high soil $\mathrm{pH}$, high calcium carbonate content, high organic matter, low moisture, high clay and phosphates can fix zinc in the soil reduce the zinc available to plants, and plants can suffer from zinc deficiency (Imtiaz, 1993 \& Alloway, 2008), Figure. 2).

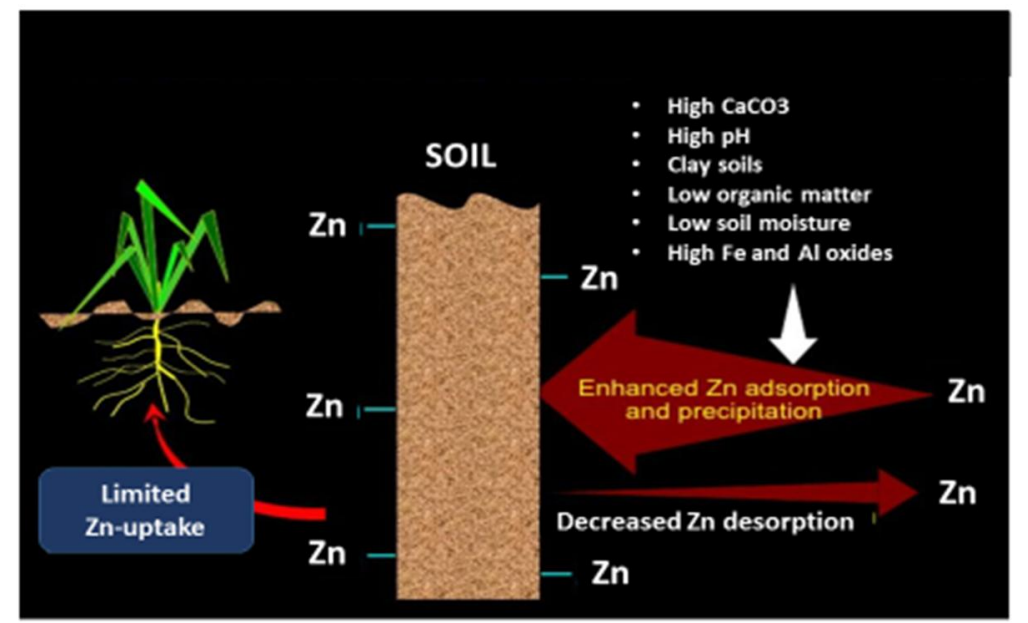

Figure 2: Schematic diagram of soil factors causing lack of zinc available for plant roots. Adapted from Alloway, (2008)

Generally, Zn deficiency in the soils is expected in calcareous soils, sandy or peat soils, and soils with high silicon and phosphorus content (Alloway, $2004 \&$ 2008). Also, the submerged soils are well recognized to have low $\mathrm{Zn}$ availability and plants can suffer from Zn-deficiency (Mikkelesen \& Shiou, 1977). Flooding and submergence conditions bring about a decline in available $\mathrm{Zn}$ because of the changes in $\mathrm{pH}$ value, particularly due to the reaction of $\mathrm{Zn}$ with free sulphide and the formation of insoluble $\mathrm{Zn}$ compounds (Mikkelesen \& Shiou, 1977). According to the Food and Agriculture Organization (FAO), about $30 \%$ of the cultivable soils of the world contain low levels of available $\mathrm{Zn}$ (Sillanpää, 1990). The lowest Zn concentrations were always more pronounced in Spodosols (28 mg $\mathrm{kg}^{-1}$ ) and luvisols (35 mg kg-1), while higher levels were found in Histosols $\left(58 \mathrm{mg} \mathrm{kg}^{-1}\right)$ and fluvisols $\left(60 \mathrm{mg} \mathrm{kg}^{-1}\right)$ (Kiekens, 1995). Meanwhile, insoluble zinc compounds are likely to be formed as a result of reaction with manganese and iron hydroxides, decomposition of oxides and absorption of carbonates, specifically magnesium carbonate, and under submerged conditions as in the case of rice cultivation, the zinc turns into amorphous deposits or franklinite; $\mathrm{ZnFe}_{2} \mathrm{O}_{4}$ (Sajwan \& Lindsay, 1988). The conversion and distribution of different forms of zinc and iron under submergence conditions for forty soils were studied by Wani and Khan (2013), They found that $>83 \%$ of total $\mathrm{Zn}$ occurred in the relatively inactive clay lattice-bound form, while a smaller fractions, viz. 1.09, 1.82, 2.27 and $11.70 \%$ of the total zinc occurred as water-soluble plus exchangeable, organic complexed, and crystalline sesquioxide bound, and amorphous sesquioxide-bound forms, respectively.

\subsubsection{Factors causes zinc deficiency in the soils}

Most of the zinc present in soil occurs on surfaces of clays, hydrous oxides, and organic matter, and little of it is found in the soil solution (Armour et al., 1990). In arid and semi-arid soils, calcite soils and the slightly acidic, leached soils of warm and tropical climates are most inclined to $\mathrm{Zn}$ deficiency, however, crops cultivated in such soil are not equally susceptible to $\mathrm{Zn}$ deficiency, where at the same soil, only some crops may suffer from $\mathrm{Zn}$ deficiency, while others are not affected. Generally, major $\mathrm{Zn}$ deficiency is common in soils with the subsequent characteristics:(i) Soils poor in zinc (parent 
material), (ii) soils of high $\mathrm{pH}$ (e.g. Calcareous \& heavy limed soils, (iii) soils rich in phosphorus (heavy P-fertilization), (iv) high soil moisture, (vi) soils of low or high organic matter content. Under these conditions, the available-Zn will be low and they will suffer from a lack of zinc (Zn-deficiency), which reduce their growth and productivity (Figure 3), and impaired quality of the cultivated crop (Lindsay, 1972; Takkar and Randhawa, 1978; Pendias and Pendias,1992; Alloway, 2004).

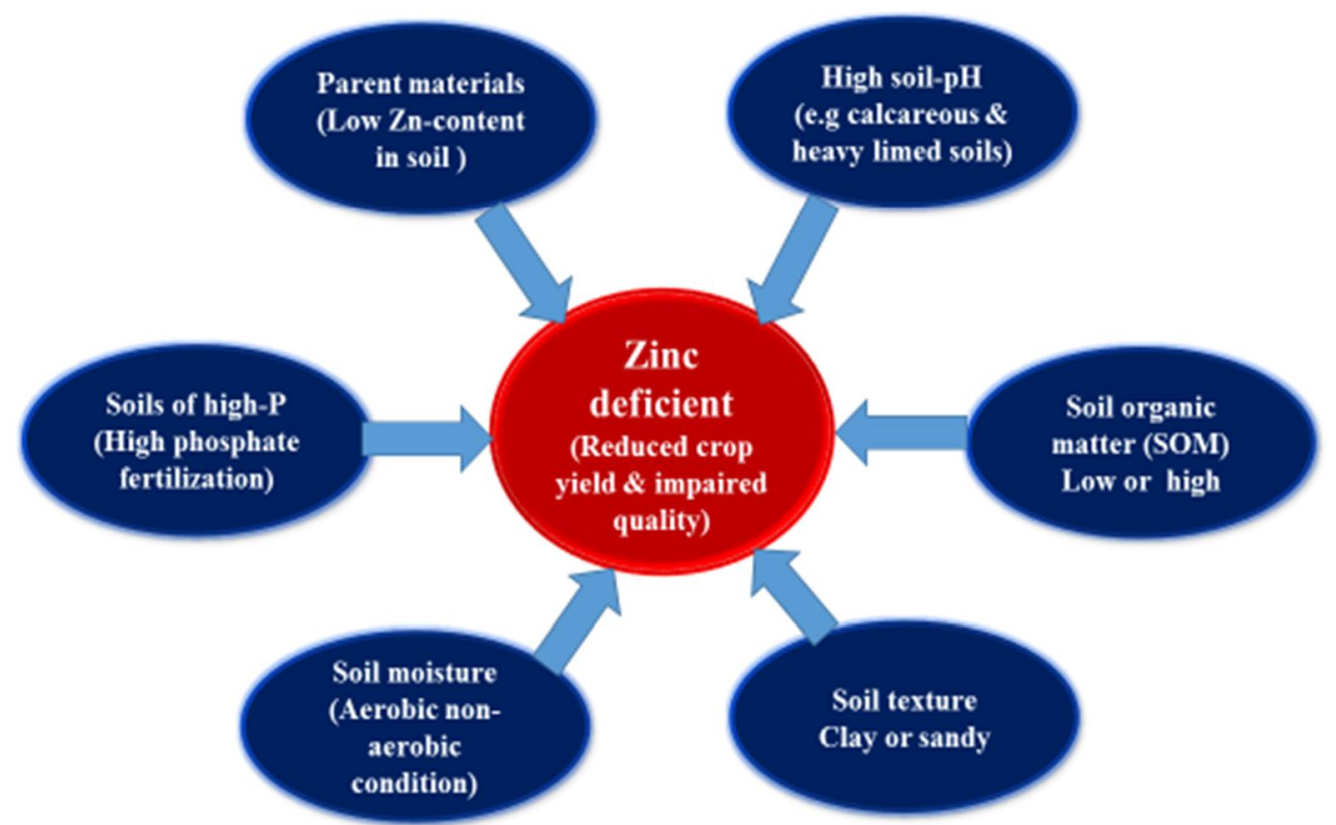

Figure 3: Schematic diagram of Zn-deficiency causes and their implication on crops. Adopted after: Alloway, 2004; Lindsay, 1972; Pendias and Pendias, 1992; Takkar and Randhawa, 1978).

\subsubsection{Parent material of soils (Soils of low $\mathrm{Zn}$ content)}

Distributions of zinc and other micronutrient vary with parent materials and profile depths (Verma et al., 2005). Zn-concentration in the soils parent material is one of the major factors affecting the soils zinc content, which is mainly depend on the chemical decomposition of the soil parent materials and the extent of weathering processes (Chesworth, 1991). It has been reported that shale soils are rich in carbonate and bound trace metal fractions (Hiller, 2006), while soils derived from false bedded sandstones are usually rich in Fe \& Mn oxides that bound trace metal fractions (Gideon et al., 2014). Total zinc in the soils were in decreasing order of Imo clay shale $>$ false bedded sandstones $>$ coastal plain sands $>$ alluvium, respectively. On the other hand, available zinc concentrations were found to be low and varied among the soils of different parent materials in a decreasing order as follows: alluvium $>$ Imo clay shale $>$ false bedded sandstones $>$ coastal plain sands (Okoli et al., 2016). The amounts of $\mathrm{Zn}$ in natural (unfertilized and unpolluted) soils are typically lower than $125 \mathrm{ppm}$ (Hussain et al., 2013). The soils derived from gneisses and granites and also those originating from sandstone (Sandy soils) and limestone (Calcareous soils) contain low total Zn content (Pendias and Pendias, 1992; Barak and Helmke, 1993; Lantican et al., 2003). Quartz particles contain rare zinc and are not able to adsorb cations and so the adsorptive capacity of a sandy soil is dependent on its low content of clay or silt-sized material and organic matter content, and due to their high infiltration rates. (De Datta, 1989; Alloway, 2009). More Quartz in sandy soils dilutes soil $\mathrm{Zn}$, which is very low in nature; ranges between $1-8 \mu \mathrm{g} \mathrm{g}^{-1}$ (Brehler and Wedepohi, 1978). Also highly leached acid sandy soil contain low total $\mathrm{Zn}$ $(<30 \mu \mathrm{g} \mathrm{g}-1)$, and generally have low available Zn (Stahl \&James, 1991).In the magmatic rocks, zinc is ranges between 40 to $120 \mathrm{mg} \mathrm{kg}^{-1}$, whereas in the sedimentary rocks $\mathrm{Zn}$ contents vary from 80 to 120 $\mathrm{mg} \mathrm{kg}{ }^{-1}$, in argillaceous sediments and shales soils, $\mathrm{Zn}$ content only ranges between $15-30 \mathrm{mg} \mathrm{kg}^{-1}$ in sandstones and 10-25 mg kg-1 in limestones and dolomites as shown in Table 2. (Kieknes, 1995; Kabata-Pendias \& Pendias, 1999 \&2001). 
Table 2: $\mathrm{Zn}$ content $\left(\mathrm{mg} \mathrm{kg}^{-1}\right)$ in different soils parent materials.

\begin{tabular}{ll}
\hline Soil type & Abundance $\mathbf{( m g ~ \mathbf { ~ g g } ^ { - 1 } )}$ \\
\hline Mean & $50-55$ \\
Magmatic rocks & $40-120$ \\
Argillaceous sediments & $80-120$ \\
Sandstones soil & $15-30$ \\
Limestones and dolomites soils & $10-25$ \\
\hline Source: Kieknes, (1995); Kabata-Pendias \& Pendias, (1999 \& 2001)
\end{tabular}

In agricultural soils, $\mathrm{Zn}$ is mostly unevenly distributed and its total $\mathrm{Zn}$-content varies between 10 and $300 \mathrm{mg} \mathrm{kg}^{-1}$ (Barbe, 1995), with an average of $50 \mathrm{mg} \mathrm{kg}^{-1}$ (Lindsay, 1972). However, the average of available $\mathrm{Zn}$ only ranged between 1 and $3 \mathrm{mg} \mathrm{kg}^{-1}$ (extracted by dithizone). The remainder of the total $\mathrm{Zn}$ is fixed in the soil in an insoluble or non-exchangeable form and difficult to make them available to crop (Stahl and James, 1991). Other researchers indicate that typical total Zn contents in unfertilized and uncontaminated soils vary widely and can range from 10 to $120 \mathrm{mg} \mathrm{kg}^{-1}$. The lowest $\mathrm{Zn}$ values were found in sandstones soil and the highest in argillaceous sediments soil, with an average $50-55 \mathrm{mg}$ $\mathrm{kg}^{-1}$ (Table 2) (Kieknes, 1995; Kabta-Pendias and Pendias, 1999).

\subsubsection{Soil pH}

Soil $\mathrm{pH}$ controls the solubility, mobility, and bioavailability and translocation in (Förstner, 1995). This is largely dependent on the partition of the zinc between solid and liquid soil phases through precipitation-dissolution reactions (Förstner, 1995). A negative significant correlation $(\mathrm{r}=-0.94)$ was found between exchangeable- $\mathrm{Zn}$ and soil $\mathrm{pH}$, while a positive significant correlation $(\mathrm{r}=0.92)$ between inorganic $\mathrm{Zn}$ concentrations and soil $\mathrm{pH}$ was noticed (Torri and Lavodo, 2008). As soil $\mathrm{pH}$ dependent on charges in mineral and organic soil fractions, it was found that negative charges dominate in high $\mathrm{pH}$, whereas positive charges prevail in low $\mathrm{pH}$ values (Gillman, 2007). Soil acidity increases is increased by leaching basic cations such as $\mathrm{Ca}^{+2}, \mathrm{Mg}^{+2}, \mathrm{~K}^{+}$, and $\mathrm{Na}^{+}$far beyond where they are released from the parent material, leaving $\mathrm{H}^{+}$and $\mathrm{Al}^{+3}$ ions at the places of cation exchange; Also, dissolving carbon dioxide in soil water produces carbonic acid, which hydrolyses and releases $\mathrm{H}^{+}$ions; Humic residues resulting from decomposition of soil organic matter, which produces high-density carboxyl and phenolic groups that dissociate to release $\mathrm{H}^{+}$ions; Nitrification to produce $\mathrm{H}^{+}$ions; Nitrogen removal in plant and animal products; And inputs from acid rain and nitrogen uptake by plants (White \& Broadley, 2005). Zinc availability is highly dependent on soil $\mathrm{pH}$, which considers the most important limiting factor, causing lower zinc availability and affecting the physiological and morphological processes in the plants (Singh et al., 2005; White\& Broadley, 2005). At low soil pH, zinc is usually soluble due to high desorption and low adsorption capacity. At intermediate soil $\mathrm{pH}$, the trend of trace element adsorption increases up to complete adsorption within a narrow $\mathrm{pH}$ range called the $\mathrm{pH}$ -

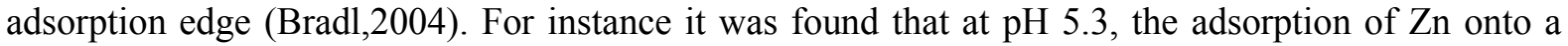
sediment composite consisting of Al, Fe, and Si-oxides was 53\% (Bradl, 2004), while, about 50\% of $\mathrm{Zn}$ sorbed onto humic acids between $\mathrm{pH} 4.8$ - 4.9 (Bradl, 2004). The fate of readily available of zinc depends on both the properties of their ionic species formed in soil solution and that of the chemical system of soil apart from soil pH itself (Kabata-Pendias, 2010). Higher carbonate contents in alkaline soils also absorb more $\mathrm{Zn}$ and hold it in a non-exchangeable form (Udo et al., 1970). Such factors contribute to lower availability of $\mathrm{Zn}$ at higher soil $\mathrm{pH}$ values, especially in calcareous soils. The low availability of $\mathrm{Zn}$ under alkaline conditions is attributed to the precipitation of $\mathrm{Zn}$ as $\mathrm{Zn}(\mathrm{OH})_{2}$ or $\mathrm{ZnCO}_{3}$ (Saeed and Fox, 1977; Shukla \& Mittal, 1979; McMahon et al., 2019). The solubility constant values for $\mathrm{ZnCO}_{3}$ and the hydroxides indicate that soils with a high $\mathrm{pH}$ typically contain a small amount of available zinc. Saeed and Fox, (1977) and Shukla \& Mittal (1979) reported that in soils with high hydroxyl (OH-) contents, it is difficult to obtain any response to zinc fertilization, due to the high soil $\mathrm{pH}$, since when the soil $\mathrm{pH}$ is above 6 , it is usually availability of zinc is very low (Fig.4). It was found that $\mathrm{Zn}$ - concentration in the soil solution decreases from $10^{-4}\left(6.5 \mu \mathrm{g} \mathrm{g}^{-1}\right)$ to $10^{-10} \mathrm{M}\left(0.007 \mu \mathrm{g} \mathrm{L}{ }^{-1}\right)$ when $\mathrm{pH}$ increased from $\mathrm{pH} 5$ to $\mathrm{pH} 8$ (Kieknes, 1995). Therefore, it is expected that $\mathrm{Zn}$ deficiency will occur in alkaline soils more than acidic one. Research has established that with increasing soil $\mathrm{pH}$, the solubility of most micronutrients and particular $\mathrm{Zn}$ will decrease, leading to low availability of $\mathrm{Zn}$ in soil solution (Kabata-Pendias, 2010). Any decrease or increase in soil $\mathrm{pH}$ produces distinct effects on 
metal solubility (Figure 4). This may probably depend on the ionic species of the elemental metals and the direction of $\mathrm{pH}$ change.

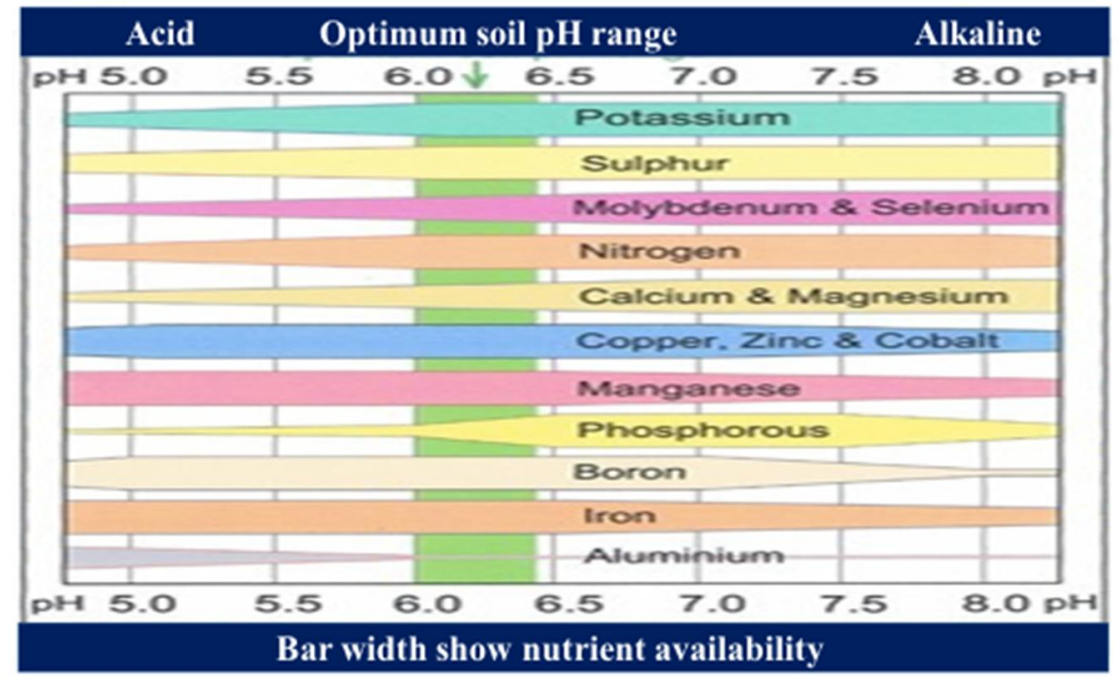

Figure 4: Zinc and other nutrients availability as affected by soil-pH.

In contrast, Förstner, (1995) found that a decrease in soil $\mathrm{pH}$ by one unit resulted in a ten-fold increase in metal solubility Rengel (2001), observed that the solubility of divalent elemental metals decreases a hundred-fold while trivalent ones experience a decrease of up to a thousand-fold due increasing soil-pH by one unit. Low available concentrations of trace element at high soil $\mathrm{pH}$ may also be caused by precipitation with carbonates, chlorides, hydroxides, phosphates, and sulphates (Cui, et al., 2016).

Apatite and lime application to soils produced the highest effect on $\mathrm{pH}$ and simultaneously decreased the concentrations of available, leachable, and bio accessible of some micronutrients (Cui, et al., 2016). Liming of acidic soils enhances soil $\mathrm{pH}$ and the $\mathrm{Zn}$ fixing capacity; particularly when soils contain high P levels (Alloway, 2004). The mobility and availability of zinc in calcareous soils is much less, than in acidic soils, so the uptake of zinc by crops may be low, and it is a zinc deficient crop (Viets, 1966; Shukla and Moris, 1967).

\subsubsection{Soil Organic Matter \& Dissolved Organic Carbon}

Soil Organic Matter (SOM) and Dissolved Organic Carbon (DOC) is the most important soil constituent that originates from decomposition of animal and plant residues. Adding organic materials such as crop residues, compost, livestock manure, green manure, and municipal bio-solids to the soil has many benefits to the soil including zinc nutrition as well as additional supply of some other benefits as improving soil structure and enhancing ion exchange capacity and water storage capacity, drainage and aeration and reducing soil salinity (Dhaliwal et al., 2019).

Soil organic carbon (SOC) content is the most important component in maintaining soil quality due to its essential role in improving physical, chemical and biological properties of soil (Dahliwal et al., 2019).Dissolution and availability of micronutrients in the soil as well as their absorption capacity by plants is greatly affected by soil organic matter as noted in many research findings, either in a direct and indirect way (Rengel et al., 1999, Dahliwal et al., 2019). Humic acid and fulvic are the two most stable organic ingredients in the soil. Both of these substances contain a relatively large number of functional groups $(\mathrm{OH}, \mathrm{COOH}, \mathrm{SH})$ that have a high affinity to metal ions such as $\mathrm{Zn}^{2+}$. Low organic matter in soil give rise to $\mathrm{Zn}$ deficiency, however, if the organic matter content in soil is too high, like in peat and muck soils, this can also causes $\mathrm{Zn}$ deficiency due to the binding of $\mathrm{Zn}$ on solid humic substances (Katyal \& Randhawa, 1983). He et al., (2019) noticed a remarkable decreasing in concentration of free $\mathrm{Zn}^{2+}$ ions in the presence of dissolved organic carbon, which could prove $\mathrm{Zn}$ binding. A decrease in the concentration of free elements in the soil solution may occur due to the binding of some minerals to the organic matter, but the dissolution of these organometallic compounds enhances the availability of these minerals in the rhizosphere root zone by increasing the concentration of total dissolved ions, which in turn depend on the movement of zinc and the degree of dissolution of 
the complexes. Dissolved organic carbon (DOC).

The reactions of humic acids with zinc as well as the stability of the complexes formed are greatly influenced by the $\mathrm{pH}$, mineral concentration, and chemical properties of soil organic molecules (Boguta and Sokolowska, 2016; Bogutaet al., 2016). The interaction of fulvic acids (FAs) with zinc could also have a beneficial role for the agricultural sector in developing effective formulations of highly stable compounds containing both organic carbon and zinc(Ray et al., 2018). The main difficulty is that both FAs molecules and $\mathrm{Zn}^{2+}$ ions exhibit high sensitivity to changes in the $\mathrm{pH}$, concentration of free metal ions, and the presence of competing ions (Wang et al.,2016\&2018).. Thus, $\mathrm{Zn}$ is chelated by FAs and increases its solubility and mobility over a wide range of soil-pH (Kiekens, 1995).

Chelating zinc with organic matter is largely responsible for increasing the accessible root forms of these nutrients and prevents the formation of insoluble forms such as carbonates and oxides in the soil (Schulin et al., 2015). Addition of organic matter to the soil stimulates microbial exudation of organic bonds (enhancing microbial biomass carbon), nutrient supply through mycorrhizal fungi, protection against root pathogens and other activities of microbes that collectively aid in the development of the root system, so zinc is one of the acquisition an essential micronutrient ability that ultimately enhances plant growth and enhances crop productivity (Schulin et al., 2015). In addition, some simple organic compounds such as amino acids and hydroxyl acids are effective in complexing zinc, thus increasing its mobility and solubility in the soil (Bendias and Bendias, 1992).

\subsubsection{Soil texture}

Soil texture plays an important role in managing soil nutrients because it affects the soil's ability to retain nutrients. For example, soils with a fine texture tend to have a greater capacity to hold soil nutrients. In soil fertility, coarse soils such as sandy soils generally have lower nutrient retention and nutrient retention capacity compared to fine soils. Therefore, sandy textured soils contain low Zn levels, while heavier textured one like clay soil absorb more $\mathrm{Zn}$ and contain more $\mathrm{Zn}$, and this adsorption is mainly affected by soil CEC and pH (Ellis \& Knzek, 1972). In this respect, Shuman (1975) and Lorenz et al.,(2000) observed that soils rich in clay or organic matter had more adsorptive capacities and higher bonding energies for zinc than sandy soils, which low in organic matter. Clay soils have higher CEC values and therefore have highly reactive sites and can retain more $\mathrm{Zn}$ than lighter sandy textured soils (Shukla \& Mittal, 1979). Cation Exchange Capacity (CEC) was found to be higher in heavier soils than sandy soils; as clay particles having a much higher cation exchange sites. (Stahl \& James, 1991). Consequently, $\mathrm{Zn}$ deficiency is more occurred in sandy soils than in clayey soils. In this context, Reddy and Perkin, (1974) proved that a certain amount of the Zn adsorbed on the clay was not exchangeable and not available to the plants and un-extractable by $0.005 \mathrm{M}$ DTPA. This depends not on only on clay amount but on clay type, since it was found that biedellite clay show up the highest capacity to fix $\mathrm{Zn}$ $(70 \%)$, followed by vermiculite $(59 \%)$ and the lower by montmorillonite $(55 \%)$. Clay systems containing hydrated mica with significant proportions of minerals such as kaolinite and vermiculite stabilized about $40 \%$ of added zinc, while clays consisting of mixed minerals, stabilized over $50 \%$ of applied zinc (Rahmatullah \& Sandhu 1985). Moreover, colloidal components such as kaolin are the components responsible for the chemical behavior of zinc in the soil (Wang et al., 2011). Specifically, the surface of kaolin is the basis of many phenomena, in particular adsorption, which occurs at the interface of the solid solution, and is affected by properties of the soil solution such as ionic strength; PH values (Zhu, et al., 2012). Reddy and Perkin, 1974) found that kaolonite stabilizes zinc to a lesser degree than bentonite or illite due to higher CEC that contribute to the fixing of $\mathrm{Zn}$ more strongly, thus making it unavailable to plants.

\subsubsection{High soil phosphorous content}

Deficiency of both phosphorous $(\mathrm{P})$ and zinc has been reported as one of the major constraints for plant growth, development and harvesting of optimal crop yield, with high nutritional value (Marschner, 2011).The interaction of $\mathrm{P}$ and $\mathrm{Zn}$ in the soil is often called "P-induced- $\mathrm{Zn}$ deficiency." As is well known, both $\mathrm{P}$ and $\mathrm{Zn}$ are considered the two nutrient components known to have antagonism in the soil plant system (Singh et al., 2005).There is a debate about the cause of this phenomenon. Some authors assert that an excess in phosphorus can lead to a decrease for zinc (Rose et al., 2015), while others concluded that this deficiency occurs due to the ability of some phosphate fertilizers to raise the soil $\mathrm{pH}$, thus increasing the availability of negatively charged compounds. They hold zinc and reduce 
the amount available to plants (Carneiro et al., 2008). Another group of authors believes that excess phosphorous in soil leads to rapid growth that is not accompanied by adequate zinc absorption, resulting in lower levels of zinc resulting from the dilution effect (Ova et al., 2015). Soils rich in phosphates, both from native phosphorous and due to heavy use or prolonged use of phosphate fertilizers, can reduce the absorption of zinc by plants (Dadlich and Somani, 2007; Alloway, 2008). In this context, many researchers mentioned that higher application of P-fertilizers caused Zn deficiency symptoms in plants (Sharma et al., 1968; Clark, 1978; Loneragan et al., 1979; Singh et al., 1986). It has been found that the addition of phosphate fertilizers reduces plant zinc availability in the soil (Pongrac et al., 2019) or zinc accumulation in the roots (Nichols et al., 2012), or affects zinc absorption. By plant nutritional status $\mathrm{P}$, which affects root system size, root exudate release, and dissolved transport in both xylem and phloem (White et al., 2012 \&2013; Bouain et al., 2014; Zhang et al., 2016). Generally, the major Zn deficiency in crop production has been/ attributed to heavier phosphate fertilizer application that inhibits $\mathrm{Zn}$ solubility in soil as well as its translocation within plant (Robson and Pitman, 1983). However, Carrol \& Loneragan (1969) reported that precipitation of $\mathrm{Zn}_{3}\left(\mathrm{PO}_{4}\right)_{2}$ does not the factor responsible about with zinc deficiency induced by high phosphorus in the soil. In plant tissues, interaction between $\mathrm{Zn}$ and $\mathrm{P}$ was reported to affect $\mathrm{Zn}^{2+}$ uptake and detoxification in some hyper accumulator plants by the precipitationof $\mathrm{Zn}$-phosphate $\left(\mathrm{Zn}_{3}\left(\mathrm{PO}_{4}\right)_{2}\right)$ (Küpper et al., 1999; Vollenweider et al., 2011; Adriano et al.,(1971)suggested that the reason for this Zn-deficiency caused by P-Zn interaction is due to the interference of $\mathrm{P}$ with the absorption, transport or use of $\mathrm{Zn}$. Studies of the interaction between $\mathrm{P}$ and Zn began in 1936 (Barnette et al., 1936), and studies of this phenomenon are still continuing to arrive at an explanation for this phenomenon (Nichols et al., 2012; White et al.,2013; Bouain et al., 2014, Zhang et al., 2016). In general, there are four possible causes responsible for zinc deficiency caused by the $\mathrm{P}$ and $\mathrm{Zn}$ reaction, which include (1) the $\mathrm{P}-\mathrm{Zn}$ reaction in the soil; (2) A slower rate of zinc transfer from the roots to the shoots; (3) A slight dilution effect on zinc concentration in the plant as a result of the growth responses to phosphorous; (4) Disruption of metabolism within plant cells associated with imbalance between $\mathrm{P}$ and $\mathrm{Zn}$ (Olsen, 1972).It was reported that formation of an insoluble $\mathrm{Zn}_{3}\left(\mathrm{PO}_{4}\right)_{2}$ in the soil reduced the available $\mathrm{Zn}$ to a deficient concentration. However, these suspicions were disproved, with Aulakh \& Malhi, (2005). In this context, Cakmak and Marschner (1987) indicating that $\mathrm{Zn}_{3}\left(\mathrm{PO}_{4}\right)_{2}$ was a good source of zinc in sorghum. Cakmak and Marschner (1987) found that high concentrations of $\mathrm{P}$ in plant tissues reduce the water-soluble $\mathrm{Zn}$ and physiological availability of $\mathrm{Zn}^{2+}$ and $\mathrm{P}$ level can be considered an indicator of zinc deficiency. Thus, it has been reported that excessive zinc accumulation does not result in phosphorous deficiency (Zhao et al., 1998).

\subsubsection{Soil moisture (flooded/aerobic soils)}

Zinc is present in soil from different sources, including plant residues, which are bound to sulfur or organic matter and are oxidizable, reducible and exchangeable. Under submerged or flooding condition, redox potential is low; and zinc in soil is more easily precipitated as zinc sulphide ( $\mathrm{ZnS})$, zinc carbonate or zinc hydroxides (Mikkelesen \& Shiou, 1977; Kirk, 2004; Impa \& Johnson-Beebout, 2012; Rehman et al., 2012). Therefore, zinc deficiency is much more common on submerged soil than on dry soil. The bioavailability of zinc in soil is mainly regulated by adsorption and absorption reactions and solubility relationships between solution and solid phases (Figure 5).

Soil properties including $\mathrm{pH}$, oxidation and reduction potentials, organic matter, oxide generation and sulfur content in soil are most important factors affect the reactions of adsorption, absorption, solubility, and precipitation of zinc in the soil (Alloway, 2009). It is expected that some of these factors will change after switching to aerobic cultivation or changing the cultivated crop. For instance, rice plants grown under submerged conditions suffer from zinc deficiency in calcareous soils, while wheat grown in the same soil after rice grows naturally (Kauser et al., 1976).

The $\mathrm{pH}$ of the soil under submerged conditions turns to a neutral, while under aerobic conditions, it is returns to the original (Ponnamperuma, 1972). Redox potential will increase under aerobic condition (Gao et al., 2002). This leads to the formation of iron and manganese oxides, in which zinc can be absorbed and be less available to plants. Under aerobic conditions, zinc precipitation is reduced as zinc sulfide (ZnS) (Carbonell-Barrachina et al., 2000). Switching to aerobic culture may increase the number and types of iron oxidizing / reducing bacteria (Chen et al., 2008), the soil organic matter content may decrease under aerobic conditions due to the oxidation that occurs to it and this may in turn significantly affect the concentration and profile of zinc in the soil solution. Precipitation of $\mathrm{Zn}$ as 
zinc sulphide (ZnS) decreases under aerobic conditions (Carbonell-Barrachina et al., 2000). Gao et al., (2006, 2010) observed in field studies in calcareous soil, that shifting from flooded to aerobic, rice suffered from $\mathrm{Zn}$ deficiency. The cultivation shift to aerobic may also lead to an increase in the number and diversity of Fe-oxidizing/reducing bacteria (Chen et al., 2008), which may consequently affect concentration and forms of $\mathrm{Zn}$ in the soil solution.

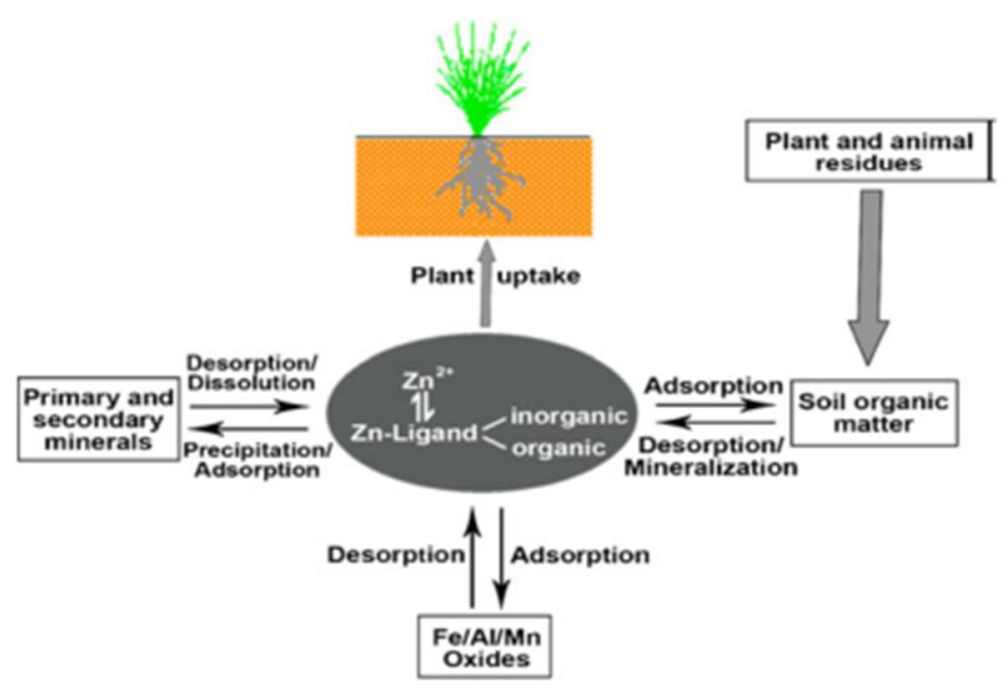

Figure 5: Soil processes affecting Zn bioavailability in soil solution after; Gao et al., (2011).

Under flooding field study by Gao et al., (2010), the precipitation of ZnS was not expected because the soil redox potential never got as negative as the level suitable for the formation of $\mathrm{ZnS}$. In contrast, the decreased Zn availability upon flooding in the pot study by Johnson-Beebout et al., (2009) coincided with a very low redox. They found in a pot experiment with calcareous soil that both soil-available $\mathrm{Zn}$ and plant $\mathrm{Zn}$ uptake increased with the oxidized soil compared with flooding one. This discrepancy in results could be due to the difference in soil sulfur content and achievable redox conditions in the two studies. In addition, under the submerged conditions of rice cultivation, zinc is converted into amorphous deposits or franklinite deposits; $\mathrm{ZnFe}_{2} \mathrm{O}_{4}$ (Singh \& Abrol, 1986; Sajwan \& Lindsay, 1988), or formed with phosphates insoluble zinc phosphate, and plant roots will not be able to absorb their zinc requirements from the soil solution and this affects plant growth and productivity.

Due to the very low availability of zinc in soil under floodding conditions, rice plants absorb most of their Zn-requirements from solubilizing $\mathrm{Zn}$ in the rhizosphere (Dobermann \& Fairhurst, 2000). On the other hand, in a non-flooding irrigated paddy soil, the exchangeable-Zn was increased and $\mathrm{Zn}$ bounded to sulfurs or organic matter was decreased. Thus, non-flooding irrigation management led to more extractability, solubility and bioavailability of $\mathrm{Zn}$ in top surface paddy soil (Mikkelesen \& Shiou, 1977). These combined observations have important implications for water management of rice on different soil types.

\subsubsection{Soil temperature}

Soil temperature effects appear to be due to the rate of $\mathrm{Zn}$ mineralization (Takkar \& Walker, 1993). Zinc deficiency appears to have been associated with cold and wet seasons. In warm and moist soils, Zn uptake was higher in rice (Oryza sativa) than in maize (Zea mays L.) (Bauer \& Lindsay, 1965). Temperatures below $16^{\circ} \mathrm{C}$ during growth decreased $\mathrm{Zn}$ availability and uptake in maize tops (Ellis $e t$ al., 1965). In addition, high light intensity and long day-lengths can cause $\mathrm{Zn}$ deficiency in plants (Marschner \& Cakmak, 1989). Therefore, adverse climatic conditions such as drought or compaction cause $\mathrm{Zn}$ deficiency besides the environmental factors and soil management practices (Alloway, 2008). Zinc availability was noticed to be low under adverse climatic conditions such as drought or in compacted soils. This Zn-deficiency is common in tropical and temperate climates, but is most widespread in the Mediterranean type of climate regions (Sillanpää \& Vlek, 1985). 


\section{Zinc in the Plants}

The requirement of zinc for plant life was questioned until 1926 when Sommer and Lipman (1926; https://www.ncbi.nlm.nih.gov/pmc/articles/PMC3648702/ - bib4) showed that zinc was required for the growth and development of sunflowers and barley. This finding resulted in zinc being generally recognized as essential for higher green plants. Maze' (Broadley et al., 2007) mentioned the essentiality of $\mathrm{Zn}$ in plant nutrition for the first time in year 1951. Zinc is the only metal encountered in each enzyme class: Oxoacid-reductase, transferases, hydrolases, lyases, isomerases, and ligases (Webb, 1992). In addition, it plays an important physiological role in plant metabolism by affecting the activities of hydrogenase and carbonic anhydrase, stabilization of ribosomal fractions and synthesis of cytochrome (Tisdale et al., 1984).

At the organism level, the important role of "zinc finger" as a structural component as it regulates transcription is worth mentioning (Klug, 1999; Englbrecht et al., 2004; Broadley et al., 2007). The regulation and maintenance of gene expression required to withstand environmental stresses in plants also depends on the adequacy of zinc in the plant (Cakmak, 2002). The plant enzymes activated by zinc are involved in maintenance of cellular membrane integrity, carbohydrate metabolism, protein synthesis, and regulation of auxin and pollen formation (Marschner, 2011 and Andresen, et al.,2018).

\subsection{Zinc absorption, transport and accumulation}

The absorption, transport, distribution and accumulation of zinc depends on the level of zinc supply of the plant, which depends on the root volume as well as mycorrhiza, which increases the surface of absorption and reduces the distance over which the zinc and other nutrients transported in the soil, and feeder canister ore (Marschner, 2011).

Seed germination and early seedling nutrition depend upon the amount of nutrient elements within seed, as seed embryo contains $\mathrm{Zn}$ among other nutrients to supply the early seedling growth with its need from this essential element (Lott \& Spitzer, 1980). Thereafter, plant develops different mechanisms to acquire nutrients from growing media for further growth, and these mechanisms varies for different plant species (Graham et al., 1992). It was found that wheat genotypes vary in their potential to absorb and translocate zinc within the plant, and they show an altered response to $\mathrm{Zn}$ deficiency, and while maize is the most cereal crops affected by zinc deficiency in soil (Moussavi-Nik et al., 1997). The conventional cereal crops synthesize more phytate compounds, resulting in higher phytate-to-Zn ratio, leading to lower Zn bioavailability for plant nutrition (Akhtar et al., 2019). Transfer of zinc to the root surface occurs mostly by diffusion, and this process is influenced by soil $\mathrm{pH}$ and moisture content (Rattan \& Deb, 1981; Marschner, 1995). Soil alkalinity reduces zinc availability due to its absorption and / or formation of less soluble compounds. The elevation of soil $\mathrm{pH}$ resulted in formation of zinc hydroxide, fixation to iron oxide $(\mathrm{FeO})$, chemical absorption over calcite and absorption on soil colloids (Alloway, 1995).For instance, an increase in soil pH from 5.5 to 7.0 caused 45 times decrease in concentration of $\mathrm{Zn}$ in the soil solution (Sarkar \& Wynjones, 1982; Marschner 2011). In general, alkaline calcareous soils are deficient in Zn (>0.5 mg kg-1 DTPA-extractable) (Alloway, 1995). As that, the accumulation of iron oxides around carbonate minerals in alkaline calcareous soils, which characterized with a $\mathrm{pH}$ more than 8, exacerbates the problem of Zn-deficiency in alkaline calcareous (Uygur \& Rimmer, 2000).

Zinc available forms include free ions, labile $\mathrm{Zn}$ and soluble organic zinc complexes (Alloway, 1995). The Zn availability in the soil is greatly affected by low-to-very high (>3\%) OM, high carbonate/bicarbonate, persistent water logging, and high concentrations of calcium (Ca), magnesium $(\mathrm{Mg}$ ), sodium (Na) (Lindsay, 1972). Soil and plant factors affecting Zn-availability, uptake, transportation and accumulation in grains of cereals and possible involved molecular mechanisms are illustrated in Figure (6), (Cakmak, 2004; Bashir et al., 2006).

Zinc deficiency in plants associated with total soil $\mathrm{Zn}$ content is defined as primary deficiency, while the deficiency due to other soil factors is classified as secondary deficiency (Sillanpää, 1982). The $\mathrm{Zn}$ deficiency is reported to become severe under rain fed conditions, especially in sandy soils of tropical regions due to strong leaching (Ekiz et al., 1998; Bagci et al., 2007). Soil phosphorus is another key factor that affecting the zinc availability.

Since year 1970, the interaction between phosphorus and zinc has been reported in mineral nutrition of many crops (Warnock, 1970; Marschner \& Schropp, 1977; Loneragan et al., 1979); however, precise role of $\mathrm{P}$ is not clear yet as how it affects $\mathrm{Zn}$ availability and translocation from root 
to shoot (Chaudhry \& Loneragan, 1970). In confirmation of this, Zhang et al., (2012) found that the heavier use of phosphorous fertilizers reduced the zinc concentration in wheat grains from 17 to $56 \%$, while other micronutrients (iron, copper, manganese) were not affected or possibly increased. In soils with low zinc, the excessive use of phosphate fertilizers exacerbates the problem of zinc deficiency in the soil and its implications on crop growth and productivity (Drissi et al., 2015; Ova et al., 2015). Under both field and controlled conditions, $\mathrm{P}$ application decreased tissue $\mathrm{Zn}$ concentration in wheat (Zou et al., 2001; Zhang et al., 2012) and other crops (Singh et al., 1988, Broadley et al., 2010) primarily due to chemical interactions of $\mathrm{P}$ in the growing media (Verma and Minhas, 1987). Indeed, upon increased phosphate fertilization, an increase in plant growth occurs, which is not matched by an increase in zinc absorbed and translocated into foliage, which leads to a dilution of zinc concentration at the cellular level (Loneragan et al., 1979). This is reported in beans, wheat, cotton, flax, soybean, tomato, grapes and citrus (Cakmak and Marschner 1986; Barrow, 1987; Singh et al., 1988; Webb and Loneragan 1988 \& 1990).

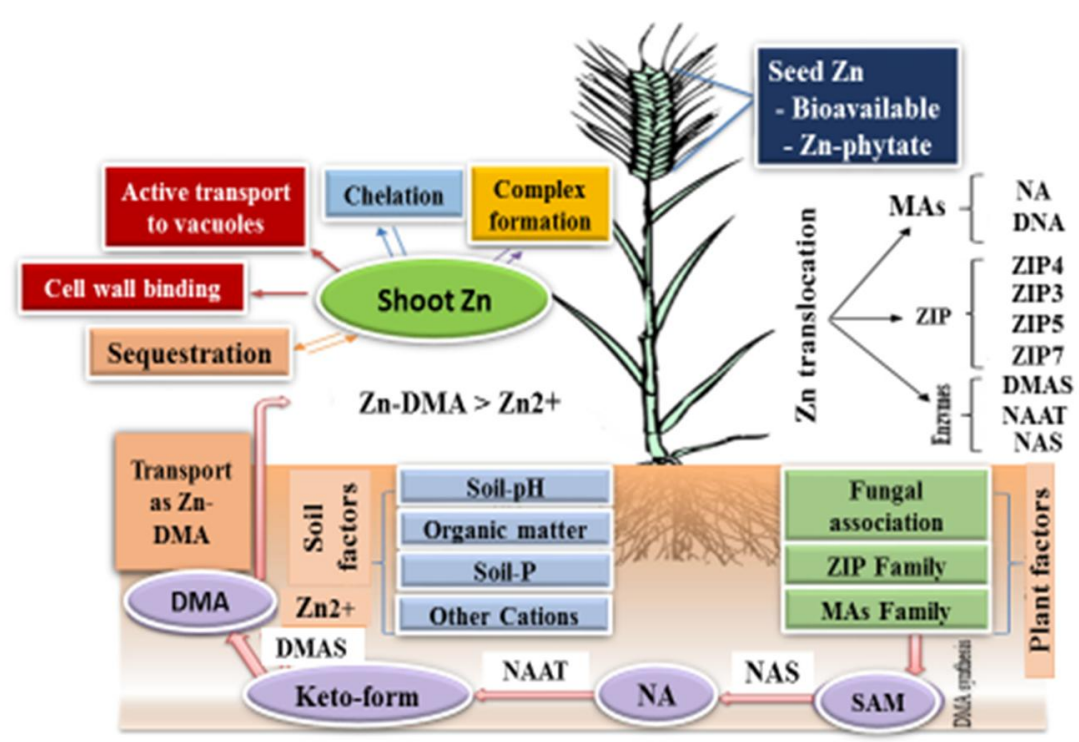

Figure 6: Illustrates soil and plant factors affecting zinc availability, uptake, transport and accumulation in grains of cereals and possible molecular mechanisms involved. Adopted from Cakmak et al., (2004), Bashir and Nishizawa (2006), Bashir et al., (2006)

The $\mathrm{Zn}$ disorder was investigated in wheat; it is binding within the root cells due to the formation of $\mathrm{Zn}$ phytate, the most common organic compound responsible to limit $\mathrm{Zn}$ translocation within plant, especially in cereals (Cakmak and Marschner 1987; Singh et al., 1988). In addition, the results exhibited that the increases in $\mathrm{P}$ rates caused substantial decrease in shoot and grain $\mathrm{Zn}$ concentrations. However, the negative effect of $\mathrm{P}$ was mitigated by the mycorrhizae association, which facilitated zinc uptake through an extended rooting system (Ova et al., 2015). Plant absorption of zinc is affected by the presence of arbuscular mycorrhizae (AM). The mycorrhizal association works to expand the surface area of plant roots, and to increase theroot surface area of which the plant can absorb water and nutrients (Subramanian et al., 2013; Thompson et al., 2013). All plants with arbuscular mycorrhizae symbiosis showed a higher concentration of zinc (Lehmann et al., 2014). In particular, plants growing in marginal soils follow the symbiotic pathway between the plant and the mycorrhizae to acquire nutrients that slow its diffusion into the soil such as phosphate, $\mathrm{Cu}^{2+}$ and $\mathrm{Zn}^{2+}$ (Evans \& Miller 1988; Sylvia et al., 1993; Watts Williams et al., 2013).

The symbiosis of the plant and the mycorrhizae improves root morphology, facilitates absorption of nutrients and enables the host plant to withstand seasonal stress (Subramanian et al., 2008).Synthesis of zinc phosphate in root apoplastic cells may be another reason for zinc fixation and for the unequal distributionof zinc within the root and shoots (Youngdahl et al., 1977; Cakmak \& Marschner, 1987). The $\mathrm{Zn}^{65}$ labeling technique was used to highlight the role of $\mathrm{P}$ levels in the unequal distribution of zinc at root and shoots. Results revealed that, elevated P tissues have been reported to reduce water-soluble 
zinc, causing a decrease in zinc availability at the physiological level (Rahimi \& Schropp, 1984; Cakmak \& Marschner 1987).That is why the high phosphorous content of plants is considered an additional stress factor that may exacerbate the feeding disorder in plants, especially zinc (Loneragan et al., 1982; Cakmak \& Marschner, 1986; Webb \& Loneragan, 1988). A higher root-to-stem ratio represents a greater decrease in shoot growth compared to the root, which is typical evidence of $\mathrm{P}$ deficiency (Cakmak et al., 1994; Watts-Williams et al., 2013 and 2014). Under such conditions, P application may boost shoot growth and resulted in Zn dilution. However, this phenomenon is not deemed as the only mechanism responsible for negative effects of higher $\mathrm{P}$ application on tissue $\mathrm{Zn}$ concentration (Lambert et al., 1979; Loneragan et al., 1979; Singh et al., 1988; Zhang et al., 2012).

The decrease in the mycorrhizae proliferation when phosphorous was used is also the cause of the decreased absorption and accumulation of zinc by crops (Teng et al., 2013). In another study, zinc accumulation in wheat decreased with the addition of phosphorus up to $100 \mathrm{~kg} \mathrm{ha}^{-1}$ in alkaline limestone soils. However, improvement of zinc absorption was observed with mycorrhizae inoculation (Zhang et al., 2016). In addition, root-induced changes in soil $\mathrm{pH}$ and release low and high molecular weight exudates, which play an important role in increasing the availability of zinc in the soil and making it available for absorption by the crops grown on soils of low Zn. Also, roots induced acidification through Fe oxidation and cation-anion intake imbalance causes a release of zinc from these soluble fractions so that the zinc is ready to taken up by rice plants which, might be often depend on this solubilization process for the bulk of their Zn need (Kirk and Bajita, 1995). In lowland rice, rhizosphere acidification can enhance the utilization of not only P but also zinc (Kirk and Saleque, 2005).

Excretion of organic acids or phytosidrophores that are able to increase the bioavailability of zinc in the root zone is another mechanism for reducing zinc deficiency in lowland rice. The changes in the $\mathrm{pH}$ in the rhizosphere are the result of the roots secretion of protons $\left(\mathrm{H}^{+}\right)$and hydroxyl $\left(\mathrm{OH}^{-}\right)$or bicarbonate ions $\left(\mathrm{HCO}_{3}{ }^{-}\right)$due to the cationic imbalance in the plant, the development of carbon dioxide through respiration, and the secretion of low molecular weight organic acids (LMWOAs).

The form of nitrogen supply has the most prominent effect on the cation / anion uptake ratio and, consequently, on the $\mathrm{pH}$ of the soil surrounding the roots (Marschner, 2011). As rice is grown in anaerobic soils, this can lead to the release of $\mathrm{O}^{-2}$ ions from the roots and this leads to increased $\mathrm{H}^{+}$ protons release, which reduces the soil $\mathrm{pH}$ and increases the bioavailability of zinc to plants (Kirk and Bajita, 1995). Also, rice roots taken up nitrogen primarily as $\mathrm{NH}_{4}{ }^{+}$, resulting in a release of $\mathrm{H}^{+}$by roots and a consequent decrease in rhizosphere $\mathrm{pH}$ and then increased $\mathrm{Zn}$-availability. On the other hand, in the case of aerobic rice cultivation, the shift of the dominant $\mathrm{N}$-uptake form from $\mathrm{NH}_{4}$ to $\mathrm{NO}_{3}{ }^{-}$is expected to lead to exudation of $\mathrm{OH}^{-}$into the rhizosphere resulting in an increase in rhizosphere $\mathrm{pH}$ with a subsequent reduction in $\mathrm{Zn}$ availability.

Generally, rice plants absorb most of their zinc needs from the soluble in the rhizosphere because the amount of available $\mathrm{Zn}$ in soil is very low under flooding condition (Dobermann \& Fairhurst, 2000). The shift in rhizosphere $\mathrm{pH}$ because of changing $\mathrm{N}$ dynamics may be the cause of the observed reduction in $\mathrm{Zn}$ uptake in rice grown in aerobic fields compared to anaerobic flooded calcareous soils (Gao et al., 2006). Under Zn deficiency, lowland rice increased citric acid and citrate exudation and the citrate exudation capacity of different rice genotypes found to be related to their tolerance to $\mathrm{Zn}$ deficiency (Hoffland et al., 2006).

\subsection{Zinc functions in the plants:}

The optimum growth and productivity of crops in general is maintained through adequate intake of zinc in its bivalent form $\left(\mathrm{Zn}^{2+}\right)$, which performs many important functions in plants,

- As an essential nutriment for all organisms for the activation of many enzymes in plant cells, such as alcohol dehydrogenase, carbonic anhydrase, and RNA polymerase (McCall, 2000; CastilloGonzález et al., 2018).

- $\mathrm{Zn}$ is involved in the metabolism of RNA and ribosomal content in plant cells that stimulate carbohydrate, protein and DNA synthesis (Memon et al., 2017; Mohamed et al., 2019).

- In addition, zinc is an essential component of the many enzymes such as oxidoreductases, transferases, hydrolases, lyases, isomerases, ligases (Webb, 1992). Zinc is also required for the manufacture of carbonic anhydrase, a zinc-containing metallo enzyme, which plays a vital role in photosynthesis processes, due to its property to convert $\mathrm{CO}_{2}$ to $\mathrm{HCO}_{3}{ }^{-}$reversibly (Bhat et al., 2017). 
- Zinc is also required for the manufacture of amino acid tryptophan, which is a precursor of a hormone auxin (IAA), the essential hormone for growth, which acts as a catalyst for growth (Amberger, 1982; Brown et al., 1993; Alloway, 2004; Brennan, 2005; Lin et al., 2005; Hänsch \& Mendel, 2009).

- $\mathrm{Zn}$ is required to form nucleic acids, proteins, pollen formation, fertilization and germination (Marschner 2011; Hegazy et al., 2016).Zinc is also involved in the formation of Rubisco, along with several biochemical reactions being activated in photosynthesis, metabolism of carbohydrates, and lipid and nucleic acid synthesis (Brown et al., 1993; Alloway, 2004; Tsonko and Lidon, 2012; Kisko et al., 2015; Samreen et al., 2017).

- Zinc regulates the $\mathrm{pH}$ of chloroplasts and protects stromal enzymes from denaturation during rapid and drastic changes in lighting conditions (Bhat et al., 2017).

- Under Zn-deficient conditions, plant growth is inhibited due to formation of reactive oxygen species (ROS), which are considered the primary factor responsible for that (Cakmak, 2000).

- It plays an important role in managing reactive oxygen species (ROS) and protecting plant cell from oxidative stress, as well as regulating stomatal function by means of regulation of potassium content in plant cells (Alscher et al., 1997; Cakmak, 2000; Amiri et al., 2016; Samreen et al., 2017; Venkatachalam et al., 2017).

- In the thylakoid lamellae, $\mathrm{Zn}$ reduces the production of toxic hydroxyl radicals in Haber-Weiss reactions because the high affinity of Zn with cysteine and histidine (Cakmak 2000; Alloway, 2004; Brennan 2005; Disante et al., 2010; Tsonko and Lidon, 2012).

In general, plants with zinc deficiency are more susceptible to disease and oxidation, and the presence of zinc in SOD and CAT acts as an aid protecting the plant from oxidative stress, and acts as a defense mechanism against harmful pathogens. (Grewal et al., 1996; Streeter et al., 2001; Marschner, 2011; Helfenstein et al., 2015).Zinc plays an important role in the production of oxygen radicals and eliminating their toxicity. Zinc contributes to the synthesis of $\mathrm{Cu}-\mathrm{Zn}$-SOD enzyme, which is a major enzyme involved in removing toxic $\mathrm{O}^{-2}$ radicals, which can be harmful to membrane lipids and proteins (Robson, et al., 2012; Castillo-González et al., 2018). Zinc is essential for the integrity of cellular membranes and contributes to the maintenance of membranes and ion transport systems. This is through its interaction with phospholipids and sulphydryl groups of membrane proteins (Cakmak, 2002; Alloway, 2004; Dang et al., 2010; Disante et al., 2010; Kabata-Pendias and Pendias, 2001, Robson, et al.,2012). Zn-finger transcription factors are involved in the development and function of flower tissues such as anthers, tapetum, pollen and pistil secretory tissues, and it is likely that VvZIP3 plays a major role in natural flowering and fruit growth (Sharma, et al., 1987; Kobayashi et al., 1998). Zinc seems to affect the plant capacity to uptake and transport water and reduces the adverse effects of heat and salt stresses (Barcelo' and Poschenrieder 1990; Kasim, 2007; Disante et al., 2010; Peck and McDonald, 2010; Tavallali et al., 2010; Tsonko and Lidon 2012).

\subsection{Zinc deficiency in the plants}

Marschner (2011) reported that adequate zinc concentrations required for normal growth and optimum yields for most crops ranged between $15-20 \mathrm{mg} \mathrm{kg}^{-1}$ dry weights. Zinc deficiency occurs below this level as has been reported in many research works (Skoog, 1940; Alloway, 2004; Disante et al., 2010). Zinc deficiency occurs when the plant is unable to take in sufficient amounts of this essential element from its growth medium. Zinc deficiency leads to abnormalities in plants, which become visible as symptoms of deficiency such as stunted growth, chlorosis and young leaves, and sterility of spikelets. Skoog (1940) observed disturbances in stem elongation in tomatoes due to zinc deficiency. $\mathrm{Zn}$ deficiency can also adversely affect the quality of harvested products; plants susceptibility to injury by high light or temperature intensity and to infection by fungal diseases (Marschner, 1995 and 2011). Zinc deficiency can negatively affect the quality of the harvested products; as it increases susceptibility to infection with fungal diseases and resulting damage due to higher light intensity or temperature and (Marschner, 1995 and 2011).

The symptoms exhibited by plant suffering deficiencies of certain other essential nutrient elements are, in some cases, similar to those of zinc deficiency and may be confused with those of zinc or be seen together with the zinc deficiency symptoms where multiple micronutrient deficiencies occur (Cakmak and Hoffland, 2012). Zinc deficiency in plants can be increased or decreased with nitrogen 
fertilization due to the role nitrogen in promoting plant growth and, to its role, in changing the $\mathrm{pH}$ in the root environment (Alloway, 2004). Since ammonium-N ions in soil have an acidic effect, the use of $\mathrm{ZnSO}_{4}$ with simultaneous dressings of ammonium-N fertilizers was found to be effective in treating zinc deficiency compared to using $\mathrm{ZnSO}_{4}$ alone (Viets et al., 1957).

The heavier application of phosphorous fertilizers can reduce the availability of zinc in the soil (Pongrac et al., 2019) or the accumulation of zinc in the roots (Nichols et al., 2012), or affect the absorption of zinc through the nutritional status of the plant $\mathrm{P}$, which affects the growth of Roots, root growth, and dissolved transport in both xylem and phloem (White et al., 2012; White et al., 2013; Bouain et al., 2014, Zhang et al., 2016).It was found that plants growing in soil rich in phosphorous or fertilized with large quantities of phosphate fertilizers suffer from zinc deficiency. The reason for this deficiency is due to the P-Zn antagonism relationship that leads to P reduces zinc absorption, transport or use (Adriano et al., 1971; Clark, 1978; Singh et al., 1986). Calcium was found in a short-term study conducted by (Chaudhry and Loneragan, 1972) to reduce Zn absorption. In legumes, it was noticed that zinc concentrations progressively decreased with increasing $\mathrm{Ca}$ concentrations in growing medium (Bell et al., 1990). Zinc deficiency in rice causes multiple symptoms that usually appear two to three weeks after planting rice seedlings, with brown spots and streaks that may merge to completely cover old leaves, and plants remain stunted, while in severe cases, plants may die, while those who recover they will show a significant delay in ripening and a decrease in yield (Yoshida and Tanaka, 1969; Van Breemen and Castro, 1980; Neue and Lantin, 1994).

Several authors (Kauser et al., 1976; Safaya, 1976; Zhang et al., 1991; Loneragan and Webb, 1993; Noevell and Welch, 1993) have reported the interaction between zinc and other micronutrients. A strong $\mathrm{Cu}-\mathrm{Zn}$ antagonism relation has been observed in wheat growing on soils deficient in $\mathrm{Cu}$ and $\mathrm{Zn}$ (Kauser et al., 1976). $\mathrm{Cu}$ and $\mathrm{Zn}$ might interact in several ways, $\mathrm{Cu}$ competitively inhibits $\mathrm{Zn}$ absorption and affects the redistribution of $\mathrm{Zn}$ within plants, and $\mathrm{Zn}$ strongly depresses $\mathrm{Cu}$ absorption (Loneragan and Webb, 1993). The interaction between $\mathrm{Zn}$ and $\mathrm{Fe}$ is also a complex process. The increased application of $\mathrm{Zn}$ had a little effect or decreased Fe concentrations in the shoot of plants (Safaya, 1976; Noevell and Welch, 1993). In the same way, higher levels of iron generally have an inhibitory effect on zinc concentration in plant tissues (Zhang et al., 1991).

Crops that respond to zinc differ in their requirement from this essential element to complete their life cycle (Marschner, 2011). The expected response of different crops when grown in a deficient soil to zinc is illustrated in Table 3.

Table 3: Potential for a crop response to zinc when applied to zinc deficient soils.

\begin{tabular}{lll}
\hline Large response to Zn & $\begin{array}{l}\text { Moderate response } \\
\text { to Zn }\end{array}$ & Small response to Zn \\
\hline $\begin{array}{l}\text { Apple, dry edible beans, } \\
\text { corn, onion, snap bean, } \\
\text { sweet corn }\end{array}$ & $\begin{array}{l}\text { Grape, lettuce, } \\
\text { potato, soybean, } \\
\text { tomato }\end{array}$ & $\begin{array}{l}\text { Alfalfa, asparagus, barley, canola, carrot, } \\
\text { clovers, grass pasture, oat, peas, rye, sugar beet, } \\
\text { sunflower, wheat }\end{array}$ \\
\hline
\end{tabular}

\subsubsection{Types of Zn-deficiency Symptoms}

The different types of Zn-deficiency symptom in plants are summarized by Skoog 1940); Weir and Cresswell, 1993; Weir et al., 1995; Alloway, 2008 and Rudani et al., 2018) as follows:

Chlorosis: This is a change in the color of the leaf from a regular chlorophyll green color to a pale green and yellow, or even white in some cases. Chlorosis appears between the ribs of grains and herbs (monocotyledons) and between the veins of plants with broad leaves (dicotyledons) and this is referred to as inter-venous. Young leaves are the most affected by Zn-deficiency, but in some cases, both old and new leaves are chlorotic,

Necrotic spots on leaves: These occur in areas of chlorosis due to the death of leaf tissue on areas of chlorosis,

Bronzing of leaves: Color of chlorotic areas may turn to bronze,

Rosetting of leaves: Zinc-deficient in dicotyledons often have shortened internodes, so the leaves cluster on the stem to take a flower shape,

Stunting of plants: Stunted plants may occur because of reduced internode elongation or reduction in plant growth,

Dwarf leaves ('little leaf'): Small leaves that often show chlorosis, necrotic spots or bronzing, 
Malformed leaves: leaves are often narrower or have wavy margins.

Some visual symptoms on leaves of some crops towards Zn deficiency could be summarize as in Figure (6; A-F):

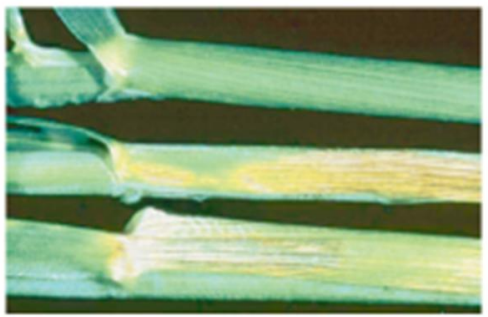

A: Wheat plant showing Chlorosis and necrotic patches on the leaves

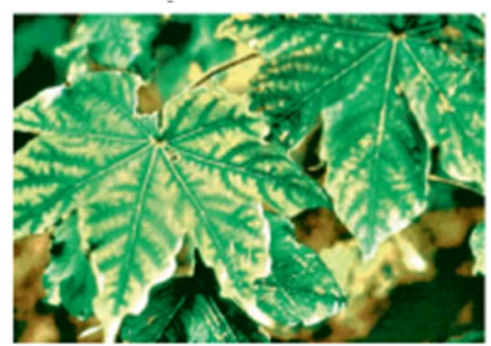

D: Cotton leaves showing large areas of interveinal chlorosis.

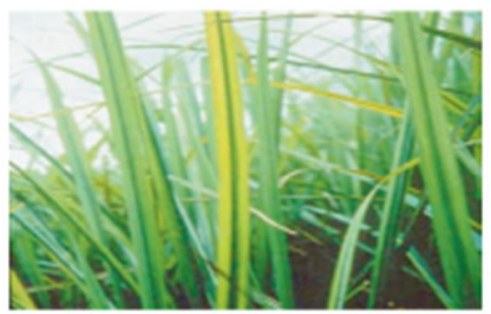

B: Sugar cane showing distinctive interveinal chlorosis on the leaves.

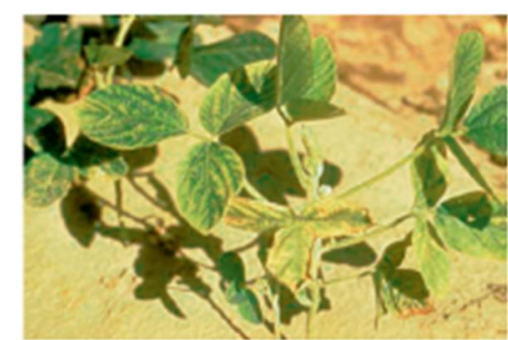

E: Soya bean showing interveinal chlorosis and bronzing of the lower leaves.

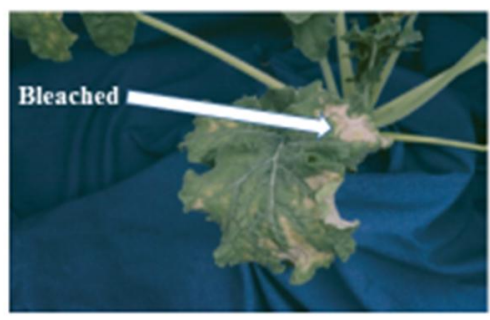

C: Oil seed rape plant showing small thickened leaves with bleached patches

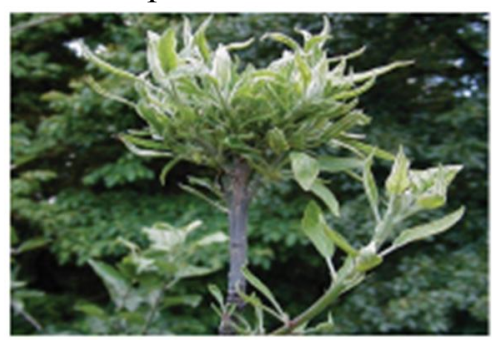

F: Apple plant showing shortened internodes giving a rosette appearance

Photos courtesy: IPNI, IANR and Yara-Phosyn.

Fig. 6: Zn-deficiency symptoms in some crops

- In Wheat: plants showing Chlorosis and necrotic spots on the leaves, (Fig. 6A),

- In Sugar cane: plants showing distinctive interveinal chlorosis on the leaves(Fig. 6B),

- In Oil seed rape: plants showing small thickened leaves with bleached patches (Fig. 6C), In Cotton: leaves showing large areas of interveinal chlorosis (Fig. 6D),

- In Soybean: leaves showing interveinal chlorosis and bronzing of the lower leaves. The symptoms of $\mathrm{Zn}$ deficiency in soybean appear first on older and/or fully expanded leaves as pale green plants (Fig. 6E),

- In Apple: plants showing shortened internodes giving a rosette appearance (Fig. 6F).

\subsection{Zinc toxicity in the plants:}

It is rare for zinc toxicity to occur in plants, unless it has been reported in some crops. Jain et al., (2013), have reported sensitivity of soya bean, sweet potato and rice towards toxic $\mathrm{Zn}$ concentration. Spinach as edible leafy vegetable crops tends to accumulate high Zn-concentrations in their leaves (Boawn and Rasmussen, 1971; McKenna et al., 1993). Normally, toxicity of Zn has been reported on acid soils, which have high Zn-content or in soils over fertilized with zinc (O'Sullivanet al., 1997). Zinc is also present in some fungicides, and may accumulate if there is excessive use of such fungicides. When soil contains high concentrations of zinc, it becomes toxic and its toxic effects depend on the bioavailability of Zn, exposure time, plant genotype, and plant development stage. Zinc toxicity may cause severe growth reduction or prevent the establishment of transplanted cuttings of sweet potato. In solution culture experiments, $\mathrm{Zn}$ concentration above $10 \mu \mathrm{M}$ in the root medium decreased sweet potato growth. At $50 \mu \mathrm{M} \mathrm{Zn}$, dark red-brown pigmentations were develops, especially near veins on older leaves (Figure 7 A\& B), growth was completely stopped (Figure 7 A), and death of roots was evident (O’Sullivan, et al., 1997).

Young leaf chlorosis induced by zinc toxicity may be due to reduced absorption of $\mathrm{Fe} 2+$ and $\mathrm{Fe} 3+$, and, in some cases, could lead to cell death (Sturikova et al., 2018). The growth retardant is the result of inhibition of mitosis, as reported in (Jain et al., 2010and Reis et al., 2018). They reported that excess zinc leads to a significant decrease in the mitotic index of Saccharum spp. and Triticum aestivum L, respectively. This decrease in mitotic activity could be due to inhibition of DNA synthesis, given 
that zinc plays an important biological role in DNA synthesis (Memon et al., 2017; Mohamed et al., 2019). In A.thaliana, treatment with zinc concentrations higher than 0.1 zinc became toxic (Jain et al., 2013). Whereas when leaves are exposed to a high level of zinc (i.e. higher than $20 \mathrm{mg} \mathrm{Kg}^{-1} \mathrm{Zn}$ ), many abnormal functions have been observed in the plant. This level of toxicity degrades the leaf tissue and at the same time lowers the productivity of the plant by making its growth stagnant.

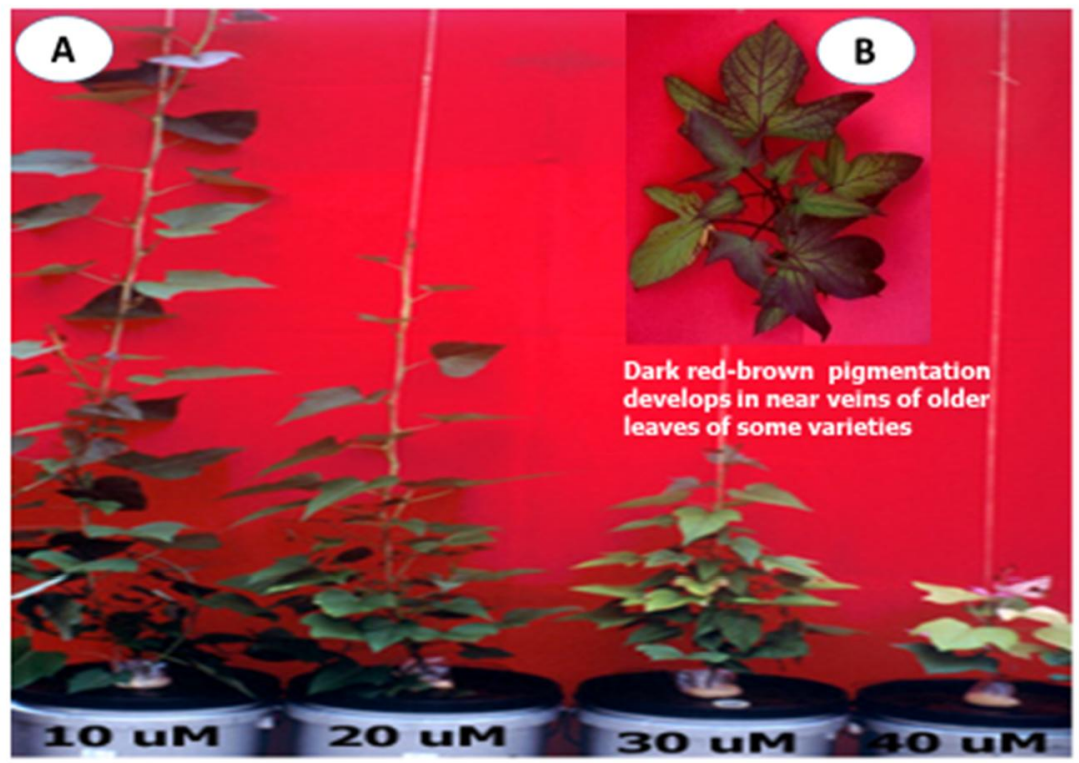

Figure 7: Zinc toxicity in sweet potato

Source: Adapted from O'Sullivan et al., (1997)

Zinc plays an important role in the production of oxygen roots in addition to removing toxins from them. The enzyme $\mathrm{Cu}-\mathrm{Zn}-\mathrm{SOD}$ is essentially localized in chloroplasts; in some plants, it is found in the thylakoid lumen whereas in others it is bound to the thylakoid (Rao and Chaitanya, 2016). $\mathrm{Zn}$ participates in the synthesis of $\mathrm{Cu}-\mathrm{Zn}-\mathrm{SOD}$ enzyme, a key enzyme involved in the removal of toxic $\mathrm{O}^{-}$ ${ }^{2}$ radicals, which can be harmful to membrane lipids and proteins (Castillo-González et al., 2018; Robson, et al., 2012). At high zinc concentrations, it becomes toxic; however, when zinc-tolerant plants are exposed to toxic levels of zinc, they accumulate zinc in the cells of their root cortex and in the leaves, specifically in the cell walls or vacuoles (Robson, 1994). Yellowing and inhibition of young leaf growth are two of the most frequently identified manifestations of zinc toxicity, possibly due to reduced absorption of $\mathrm{Fe}^{2+}$ and $\mathrm{Fe}^{3+}$, and may in some cases lead to cell death (Sturikova et al., 2018). Phosphorous can be used to reduce the toxic effect of zinc excess since the interaction between $\mathrm{Zn}$ and $\mathrm{P}$ in plant tissues leads to zinc precipitation and reduces its toxic effect (Cakmak and Marschner 1987; Küpper et al., 1999 and Vollenweider et al., 2011).However, it was reported that high Zn concentration in Zn-hyper accumulator plants did not induce P-deficiency (Zhao et al., 1998).

\subsubsection{Effect of excess-Zn on seed germination}

Seed germination is greatly influenced by seed content and the availability of zinc in the growing medium and this effect mainly depends on the plant species (Balafrej et al., 2020). The results of several studies revealed that excess zinc concentration in the growing medium significantly reduced the germination of several plants (Marichali et al., 2014; Gokak \& Taranath 2015; Zhi et al., 2015; Ivanov et al., 2016; Marichali et al., 2016). For example, Basha \& Selvaraju, 2015; Gupta et al., 2016; Nanda \& Agrawal, 2016; Bae et al., 2017) reported that high Zn-concentrations considerably reduce the germination of Vigna unguiculata, Cassia angustifolia, and Glycine max.

\subsubsection{Effect of excess- $\mathrm{Zn}$ on roots development:}

Plant roots are an important part affecting the bioavailability of the soil's indigenous and exogenous $\mathrm{Zn}$. It is well known that roots interact with the rhizosphere and causes several modifications in the rhizospheric soil proprieties, as the $\mathrm{pH}$, microbial activity, chemical equilibrium, mobility, and 
Zn-bioavailability (Clemente, 2010; Seshadri et al., 2015). Such modifications are induced by root exudates that affect the nutrients and metal availability. Root exudates are released in the soil by root cells, including low molecular weight compounds (phenolic compounds,amino acids, organic acids, and sugars) and compounds of high molecular weight (polysaccharides and proteins) (Chen et al., 2017; Hou et al., 2017). In Arabidopsis halleri, (Tsednee et al., 2014), observed that roots release nicotianamine (NA), a main chelator, which has a beneficial effect on improving Zn's solubility and thus $\mathrm{Zn}$ availability and uptake. In Hordeum vulgar, Lolium perenne L., and different dicots species, roots produce organic compounds, which form complexes with $\mathrm{Zn}$, thus promoting its solubility, and mobility and availability (Wei-Hong et al., 2007; Degryse et al., 2008; Versieren et al., 2014).

In addition, exposure of the roots to excess zinc caused major alterations in the architecture of their roots (Disante et al., 2014). In fact, several studies revealed that plants exposed to high concentrations of heavy metals exhibited changes in their root morphology and developed more root branching with marked curvature and higher branching ratio in the area of contact with the metal (Bochicchio et al., 2015; Emamverdian et al., 2015; Küpper \& Andresen, 2016; Mustafa \&Komatsu, 2016). The suppression of root elongation due to excess zinc has been explained by the loss of cell root tips viability, inhibition of cell proliferation and subsequent elongation (Marichali, et al., 2016 and Li et al., 2020). In Senna multijugaand Erythrina crista-galli, it was noticed that high concentration of zinc in the soil induced a linear decrease of the root-specific superficial area, and reduces their capacity for water and nutrient absorption (Scheid et al., 2017). In Beta vulgaris L, Zn-excess in growing media induces a reduction in the root growth, displaying a brown color with short lateral roots and arrested metabolism processes in the roots (Sagardoy et al., 2011). In several plant species, roots are commonly generated hydrogen peroxide $\left(\mathrm{H}_{2} \mathrm{O}_{2}\right)$ and superoxide anion $\left(\mathrm{O}^{2-}\right)$ as reactive oxygen species (ROS), when exposed to excess $\mathrm{Zn}$ in growing media (Miller et al., 2007 and Anwaar et al., 2015), which leads to disassembly of the thylakoids ( $\mathrm{Li}$ et al., 2013).

\subsubsection{Effect of excess- $\mathrm{Zn}$ on plant shoots}

Photosynthesis processes and consequently plant growth is one of the mechanisms that affected by zinc toxicity (Khan \& Khan, 2014). For example, in Solanum lycopersicum, toxic Zn-concentration $(43 \mathrm{ppm})$ caused leaf chlorosis and negatively reduced plant growth due to its adverse on photosynthetic electron transport, loss of plasma membrane integrity, and a decrease of bio-membrane permeability, which result in photosynthesis impairment (Monnet et al., 2001; Cambrollé et al., 2012; Vijayarengan \& Mahalakshmi, 2013). Linked with lack of photosynthetic activity in plant foliage, reactive oxygen species (ROS), such as $\mathrm{O}^{2-}$ or $\mathrm{H}_{2} \mathrm{O}_{2}$ are generated, which leads to disassembly of the thylakoids (Azzarello et al., 2012; Li et al., 2013). Beta vulgaris L. plants grown with excess zinc showed symptoms of stress such as rolling the edges of leaves inward and reduced overall metabolism due to reduced photosynthetic efficiency (PSII) (Sagardoy et al., 2011). Zinc stress reduces the rate of photosynthesis and induces the generation of reactive oxygen species ( $\mathrm{Li}$ et al., 2013), by catalyzing ROS-producing enzymes, such as nicotinamide Adenine Dinucleotide Phosphate Hydrogen Oxidases (NADPH), to replace the basic cations from specific enzyme binding sites, Or inhibit enzyme activities (Hussain et al., 2013). This can lead to lipid oxidation, protein impairment, enzyme inactivation, and DNA damage (Miller et al., 2007).Proline accumulation in the aerial parts of plants is a widespread process among higher plants in response to excess zinc and other heavy metal stresses. It is hypothesized that proline increases plant tolerance to heavy metal stress through several mechanisms, such as (1) osmoregulation, (2) stabilization of protein synthesis, and (3) enzyme protection against denaturation (Tripathi \& Gaur, 2004). In addition, proline accumulation has been shown to alleviate metal-induced oxidative stress by cleaning up toxic ROS (Michael \& Krishnaswamy, 2011).

\section{Zinc in human health}

The importance of zinc in the nutrition of higher animals was reported in 1919 by Birckner when he discovered the presence of zinc in egg yolks as well as in cow and human milk, and from here it was inferred that the element zinc has an important nutritional function, and considered an essential element in human nutrition (White and Broadley, 2005; Graham et al., 2012). At year 1963, only three enzymes were known that required zinc for their activities, but now $>300$ enzymes and $>1000$ transcription factors are known to require zinc for their normal activities(Anderson et al., 2001; Barnett et al., 2010; Prasad, 2017). Zinc is also essential for tissue growth, wound healing, taste acuteness, connective tissue 
growth and maintenance, immune system function, prostaglandin production, odor, vision, taste and appetite, healthy skin growth, mineralization of bones, hair and nails, proper thyroid function, blood clotting, and cognitive functions, cell division, sperm production, protein and DNA synthesis, and embryo development (Bhowmik, et al., 2010). Zinc in the human body interacts with a large number of enzymes and proteins, and around 3,000 protein and 300 enzymes are Zn-dependent (Anderson et al., 2001; Andreini et al., 2006; Barnett et al., 2010; Krezel \& Maret, 2016). It plays an important structural, functional and regulatory role, activates cellular metabolism and stimulates the immune system (Lukaski, 2004; Morley, 2004; Bonaventura et al., 2015). Zn is necessary element for proper human growth and development during, especially childhood, adolescence, and pregnancy. It has been estimated that one-third of the world's population lack sufficient $\mathrm{Zn}$ for adequate nutrition,and to be at risk of $\mathrm{Zn}$ deficiency, which is especially prevalent in children under 5 years age, due to their relatively large demand for $\mathrm{Zn}$ to support growth and development requirement from this element (Wessells \& Brown, 2012). Zinc remains a serious health problem in developing countries, mainly due to insufficient dietary zinc intake. The reason for this is the dependence of the population on cereal-based foods with small $\mathrm{Zn}$ concentrations, which cannot meet the human need for this vital element. Because, most modern cereal varieties naturally contain very small concentrations of zinc (Cakmak and Kutman, 2017).In addition, approximately $50 \%$ of wheat-cultivated soils globally are poor in bio-available-Zn. The major factor contributing to deficiency of zinc in human is high phytate-containing cereal protein intake, especially in the developing countries, and nearly 2 billion of the world's population may be subjected to zinc deficient (Prasad, 2017).As well, every year, about half a million children under the age of five die from diseases associated with zinc deficiency (Stein et al., 2005; Black et al., 2008; Krebs et al., 2014).

Daily intake of zinc is important for humans because the mammalian body has a limited potential to store zinc, and the daily requirement of humans for zinc varies according to gender and physiological stage (Hambidge and Krebs, 2001). According to the National Institute of Health Office of Dietary Supplements, recommended dietary allowance (RDAs) for $\mathrm{Zn}$ are 2-3 $\mathrm{mg} \mathrm{day}^{-1}$ in infants, $5 \mathrm{mg}^{-1 a y}{ }^{-1}$ in children, 8-11 mg day ${ }^{-1}$ in adolescents and adults, and 11-13 mg day for pregnant and lactating women (Table 4). The US adequate-Zn intake or what is called "Recommended Daily Allowance" (RDAs) is 8.0-13.0 mg day ${ }^{-1}$ and the UK guidance daily "Reference Nutrient Intake" (RNI) is 7.0-13.0 $\mathrm{mg} \mathrm{day}^{-1}$ for adults (Department of Health (UK), 1991; Institute of Medicine (USA), 2001; FAO/WHO, 2002; Hotz \& Brown, 2004).

Table 4: Recommended Dietary Allowances (RDAS) of Zinc for human (mg day-1)

\begin{tabular}{lcccc}
\hline Age & Male & Female & Pregnancy & Lactation \\
\hline 0-6 months & $2 \mathrm{mg} *$ & $2 \mathrm{mg*}$ & & \\
7-12 months & $3 \mathrm{mg}$ & $3 \mathrm{mg}$ & & \\
1-3 years & $3 \mathrm{mg}$ & $3 \mathrm{mg}$ & & \\
4-8 years & $5 \mathrm{mg}$ & $5 \mathrm{mg}$ & & \\
9-13 years & $8 \mathrm{mg}$ & $8 \mathrm{mg}$ & & \\
14-18 years & $11 \mathrm{mg}$ & $9 \mathrm{mg}$ & $12 \mathrm{mg}$ & $13 \mathrm{mg}$ \\
19+ years & $11 \mathrm{mg}$ & $8 \mathrm{mg}$ & $11 \mathrm{mg}$ & $12 \mathrm{mg}$ \\
\hline
\end{tabular}

*Adequate Intake (AI)

Source: Institute of Medicine, Food and Nutrition Board, Washington, DC: National Academy Press, (2001).

\subsection{Zinc deficiency in human}

Unfortunately, the diets of many people around the world lead to a deficiency of zinc in their diet (White and Broadley, 2009; Bouis and Welch, 2010; Stein, 2010; Sayre et al., 2011). This is due to the sourcing of food products from lands that are poor in zinc, which leads to the consumption of products containing low $\mathrm{Zn}$ concentrations It is estimated that nearly a third of the world's population consumes less zinc compared to the US RDAs and that zinc deficiency contributes to 1.9 percent $\%$ of the total burden of disease from major health hazards worldwide (WHO, 2002; Hotz and Brown, 2004). This has considerable socio-economic negative impacts (Solomons, 2000; Stein, 2010).Zinc deficiency is recognized as one of the major nutrient disorders in human nutrition and is more marked in children (Boonchuay et al., 2013), and in developing countries (Darton-Hill et al., 2005; Stein, 2014). Zinc 
deficiency is associated with a wide range of illnesses and diseases in humans (Black et al., 2008; Gibson, 2012; Krebs et al., 2014; Gibson, 2015; Terrin et al., 2015), including stunted growth (more severe in children), impaired immune system function (Prasad, 2009; Barnett et al., 2010), cancer (Hotez and Brown, 2004), susceptibility to infectious diseases, iron deficiency anemia, poor birth outcomes in pregnant women (Prasad, 2009; Graham et al., 2012), severe dermatitis in children (Fig.8ab), hair loss (Fig.8c)), white spots on nails ( Fig.8d), change in hair color from black to reddish brown (Maret and Sandstead, 2006), skin problems, weak body muscles, pneumonia in children (Stein et al., 2005; Das and Green, 2013), and changes in neuro-sensory (abnormal taste sensation) and delayed wound healing (Prasad, 1998). High rates of morbidity and death from diarrhea, pneumonia, and skin infections in children can also occur from food-related illnesses, as seen in developing countries(Darton-Hill et al., 2005; Stein, 2014), and can lead to infertility in men (Hafeez, et al.,2013). Another adverse clinical effect of zinc deficiency in human is impairment of cognitive function (memory loss), increased oxidative stress, and regularity of inflammatory cytokines (Prasad, 2017). Poor zinc homeostasis is associated blood sugar disease; in both type 1 and type 2 diabetes (Janson $e t$ al., 2009; Chen et al., 2000; Anderson et al., 2001; Simon and Taylor, 2001; Wijesekara et al., 2009 andFoster and Samman, 2010), as zincuria is one of the symptoms of diabetes (McNair,1981; Cunningham et al., 1994; Wijesekara et al., 2009). Lymphocyte proliferation is also affected by zinc deficiency due to zinc being involved in DNA synthesis and cell division. Tymulin, a hormone involved in the maturation of $\mathrm{T}$ lymphocytes and zinc plays an important role in its formation, and thus is adversely affected by Zn- deficiency (Prasad, 1995). Zinc deficiency impairs brain function (Maret and Sandstead, 2006). In view of global COVID-19 Pandemic, potential protective effect of $\mathrm{Zn}$ is of particular interest. It is considered as potential supportive treatment in the therapy of COVID-19 infection due to its immune moduatory antiviral property, as well as its ability to regulate the inflammatory response as well as direct antiviral effect (Zhang and Liu, 2020).

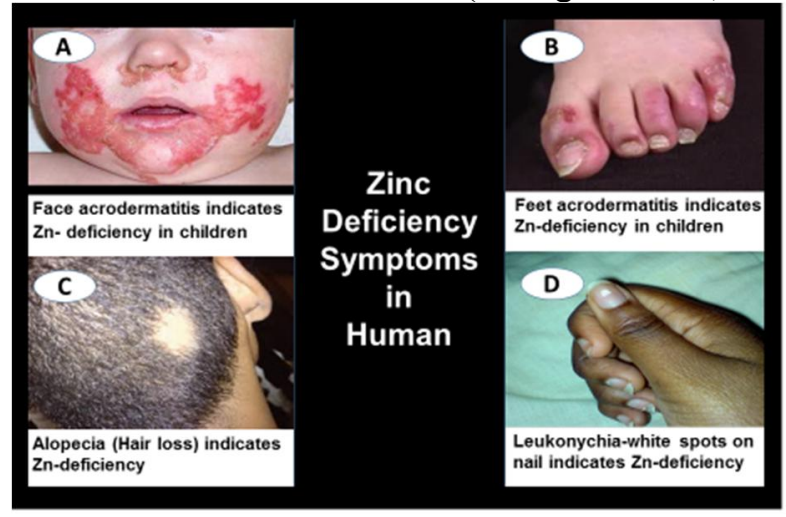

Figure 8: Zinc deficiency symptoms in human Source: Allnutriments.blogspot.com (2012)

\section{Conclusion and outlook}

Zinc is an important micronutrients required for normal growth and development of plant and human, since all living organisms need zinc to survive. Millions of hectares of cropland are affected by $\mathrm{Zn}$ deficiency, especially in rice and wheat in arid and semiarid regions having alkaline calcareous nature of soils, and approximately one-third of the world's population suffers from an inadequate intake of $\mathrm{Zn}$. All living organisms required zinc to survive and to complete their life cycle. Therefore, Zinc is important nutritional micronutrients for normal growth and development of plant and human. Ensuring adequate zinc intake by the plants is a key component of efforts to increase crop yield and quality, improve nutritional value and maintain human health, especially in developing countries. Therefore, plants require a necessary and continuous supply of zinc throughout their entire growth phases to achieve optimum productivity. Basic knowledge of the amount and dynamics of zinc ( $\mathrm{Zn})$ in soil, water and plants is an important and priority research topic, especially in areas where zinc deficiency is prevalent such as arid and semi-arid regions in developing countries in order to achieve sustainable solutions to the problem of zinc deficiency in crops and people. Low genetic potential of existing cereal crop cultivars to uptake and accumulate $\mathrm{Zn}$ in grains is a major limitation factor for crop production and human health. To overcome the Zn deficiency problem in plant and human, future way forward 
demands extensive research in fields of nutrient cycling and zinc fluxes in soil-plant systems using modified techniques/application methods, agronomic practices, exploration of new nutrient sources including inorganic as well as develop new cultivars with improved nutrient use efficiency. The potential of zinc bio-fortification as an additional feature of the already existing demands related to yield, quality, insect / pest resistance, etc. is an important process for raising plant zinc levels. In addition, understanding the mechanisms of zinc accumulation in $\mathrm{Zn}$ hyper accumulators plants will greatly contribute to breeding and engineering new species of staple crops that have the required zinc concentrations.

\section{References}

Abreu, C.A., A.S. Lopes, and G.C.G. Santos, 2007. Micronutrients. p. 645 - 736. In: Novais, R.F., Alvarez, V.H., Barros, N.F., Fontes, R.L.F., Cantarutti, R.B., Barros, N.F., Fontes, R.L.F., Neves, J.C.L., eds . Soil fertility = Fertilidade do solo. Sociedade Brasileira de Ciência do Solo, Viçosa, MG, Brazil (in Portuguese).

Adriano, D.C., G.M. Paulson, and L.S. Murphy, 1971. P-Fe and P-Zn relationship in corn seedlings as affected by mineral nutrition. Agronomy Journal; 63: 36-39.

Akhtar, M., S. Yousaf, N. Sarwar, and S. Hussain, 2019. Zinc bio-fortification of cereals-role of phosphorus and other impediments in alkaline calcareous soils. Environ Geochem Health,41(5): 2365-2379. doi:10.1007/s10653-019-00279-6

Alexakis, D., 2011. Diagnosis of stream sediment quality and assessment of toxic element contamination sources in East Attica, Greece. Environ Earth Sci., 63:1369-1383.

Alloway, B.J., 2004. Zinc in soils and crop nutrition. International Zinc Association, Brussels, Belgium Alloway, B.J., 1995. Heavy metals in soils. London: Blackie Academic and Professional.

Alloway, B.J., 2008. Zinc in soils and crop nutrition. In $2^{\text {nd }}$ International Zinc Association (IZN) and International Fertilizer Industry Association (IFIA) Brussels, Belgium. (pp. 1- 116).

Alloway, B.J., 2009. Soil factors associated with zinc deficiency in crops and humans. Environ Geochemistry Health, 31(5):537-548. http://doi.org/10.1007/s10653-009-9255-4

Alscher, R.G., J.L. Donahue, and C.L. Cramer, 1997. Reactive oxygen species and antioxidants: Relationships in green cells. Physiol. Plant, 100: 224-233.

Amberger, A., 1982. Micronutrients and other iron problems in Egypt. Short communication. J. Plant Nutrition, 5: 967.

Amiri, A.B., C. Baninasab, A. Ghobadi and H. Khoshgoftarmanesh, 2016. Zinc soil application enhances photosynthetic capacity and antioxidant enzyme activities in almond seedlings affected by salinity stress. Photosynthetic, 54(2): 267-274.http://doi.org/10.1007/s1 1099-016-0078-0

Anderson, R.A., A.M. Roussel, N. Zouari, S. Mahjoub, J.M. Matheau, and A. Kerkeni, 2001.Potential antioxidant effects of zinc and chromium supplementation in people with type 2 diabetes mellitus. J.Am. Coll. Nutr., 20: 212-218.

Andreini, C., L. Banci, and A. Rosato, 2006. Zinc through the three domains of life. Journal of Proteome Research, 5: 3173-3178.

Andresen, A., E. Peiter, and H. Küpper, 2018. Trace metal metabolism in plants, Journal of Experimental Botany, 69 (5): 909-954. https://doi.org/10.1093/jxb/erx465

Anwaar, S.A., S. Ali, and S. Ali, et al., 2015. Silicon (Si) alleviates cotton (Gossypium hirsutum L.) from zinc $(\mathrm{Zn})$ toxicity stress by limiting $\mathrm{Zn}$ uptake and oxidative damage. Environ Sci. Pollut. Res., 22: 3441-3450. http://doi.org/10.1007/s11356-014-3938-9

Armour, J.D., G.S.P. Ritchie, and A.D. Robson, 1990. Extractable zinc in particle-size fractions of soils from Western-Australia and Queensland. Aust. J. Soil Res., 28: $387 \mathrm{e} 397$.

Aulakh, M.S., and S.S. Malhi, 2005. Interactions of nitrogen with other nutrients and water: Effect on crop yield and quality, nutrient use efficiency, carbon sequestration, and environmental pollution. Advances in Agronomy, 86: 341-409.

Azzarello, E., C. Pandolfi, C. Giordano, M. Rossi, S. Mugnai, and S. Mancuso, 2012. Ultra morphological and physiological modifications induced by high zinc levels in Paulownia tomentosa. Environ Exp Bot., 81:11-17. 
Bae, K., J. Kim, and C.K. Lim, at el., 2017. Colloidal zinc oxide-copper (I) oxide nan catalysts for selective aqueous photocatalytic carbon dioxide conversion into methane. Nat Commun. 8, 1156. http://doi.org/10.1038/s41467-017-01165-4

Bagci, S., H. Ekiz, A. Yilmaz, and I. Cakmak, 2007. Effects of zinc deficiency and drought on grain yield of field-grown wheat cultivars in Central Anatolia. Journal of Agronomy and Crop Science, 193: 198-206.

Bailey, R.L., K.P. West Jr., and R.E. Black, 2015. The epidemiology of global micronutrient deficiencies. Ann. Nutr. Metabol., 66 (2): 22-33.

Balafrej, H., D. Bogusz, Z.A. Triqui, A. Guedira, N. Bendaou, A. Smouni, and M. Fahr, 2020.Zinc Hyperaccumulation in Plants: A Review. Plants 9, 562; http://doi.org/10.3390/plants9050562

Barak, P., and P.A. Helmke, 1993. The chemistry of zinc. In A.D. Robson (Ed.), Zinc in soils and plants (pp. 1-13). Dordrecht: Springer.

Barber, S.A., 1995. Soil Nutrient Bioavailability: A Mechanistic Approach, second ed., John Wiley \& Sons, Inc, New York.

Barcelo, J. and C. Poschenrieder, 1990. Plant water relations as affected by heavy metal stress: a review. J. Plant Nutr., 13: 1-37.

Barnett, J.B., D.H. Hamer, and S.N. Meydani, 2010. Low zinc status: a new risk factor for pneumonia in the elderly? Nutrition Reviews, 68: 30-37. http://doi.org/10.1111/j.1753-4887.2009.00253.x

Barnette, R.M., J.P. Camp, J.D. Warner, and O.E. Gall, 1936. Use of zinc sulphate under corn and other field crops. Flo. Agri. Exp. Sta. Bull., 293:3.

Barrow, N., 1987. The effects of phosphate on zinc sorption by a soil. European Journal of Soil Science, 38: 453-459.

Barrow, N.J., 1993. Mechanisms of reaction of zinc with soil and soil components. Chapter 2. In A. D. Robson (Ed.), Zinc in soils and plants. Developments in Plant and Soil Sciences, 55: 15- 32. Springer, Dordrecht, Kluwer Academic Publishers.

Basha, S.A. and M. Selvaraju, 2015. Toxic effect of zinc on growth and nutrient accumulation in cow (Vigna unguiculata .L). International Letters of Natural Sciences, 43: 48-53. http://doi.org/10.18052/ILNS.43.48www.scipress.com

Bashir, K., H. Inoue, S. Nagasaka, M. Takahashi, H. Nakanishi, S. Mori, et al.,2006. Cloning and characterization of deoxymugineic acid synthase genes from graminaceous plants. Journal of Biological Chemistry, 281: 32395-32402.

Bauer, A., and W.L. Lindsay, 1965.The effect of soil temperature on the availability of indigenous soil zinc. Soil Science Society of America. Proc., 29: 413-420.

Begum, K., and M.D.F. Hossain, and D.R. Parveen, 2016. Distribution of Zinc Fractions in Relation to Properties of Some Soils of Bangladesh. Dhaka University Journal of Biological Sciences, 25: 1925. $10.3329 /$ dujbs.v25i1.28491

Bell, R.W., G. Kirk, D. Plaskell, and J.F. Loneragan, 1990. Diagnosis of zinc deficiency in peanut by plant analysis. Communication Soil Sci. Plant Analysis, 21: 273-285.

Bhat, F.A., B.A. Ganai, and B. Uqab, 2017. Carbonic anhydrase: Mechanism, Structure and Importance in Higher Plants, Asian Journal of Plant Science and Research, 7(3):17- 23.

Bhowmik, D., K.P. Chiranjib, and S. Kumar, 2010. A potential medicinal importance of zinc in human health and chronic disease. Int. J Pharm Biomed Sci., 1(1): 05-11.

Biesalski, H.K., 2016. Nutrition meets the microbiome: micronutrients and the microbiota. Ann., N. Y., Acad Sci, 1372: 53-64. http://doi.org/10.1111/nyas.13145

Birckner V., 1919. The zinc content of some food products. J Biol. Chem., 38:191-203.

Bityutski, N., K. Yakkonen, A. Petrova, and M. Nadporozhskaya, 2017. Xylem sap mineral analyses as a rapid method for estimation plant-availability of $\mathrm{Fe}, \mathrm{Zn}$ and $\mathrm{Mn}$ in carbonate soils: a case study in cucumber. J Soil Sci Plant Nutr., 17 (2):279-290.

Black, R.E., H.A. Lindsay, Z.A. Bhutta, L.E. Caulfield, M. de Onnis, M. Ezzati, et al., 2008. Maternal and child undernutrition: global and regional exposures and health consequences. Lancet, 371:243-260.

Boawn, L.C. and P.E. Rasmussen, 1971. Crop response to excessive zinc fertilization of alkaline soil. Agronomy J. 63(6):874-876

Bochicchio, R., A. Sofo, R. Terzano, C.E. Gattullo, M. Amato, and A. Scopa, 2015. Root architecture and morphometric analysis of Arabidopsis thaliana grown in $\mathrm{Cd} / \mathrm{Cu} / \mathrm{Zn}$-gradient agar dishes: $\mathrm{A}$ 
new screening technique for studying plant response to metals. Plant Physiology and Biochemistry, 91: 20-27.

Boguta, P. and Z. Sokołowska, 2016. Interactions of Zn (II) Ions with Humic Acids Isolated from Various Type of Soils. Effect of $\mathrm{pH}, \mathrm{Zn}$ Concentrations and Humic Acids Chemical Properties. PloS one. 11. e0153626. 10.1371/journal.pone.0153626

Boguta, P., V. D'Orazio, Z. Sokołowska, and N. Senesi, 2016. Effects of selected chemical and physicochemical properties of humic acids from peat soils on their interaction mechanisms with copper ions at various pHs. Journal of Geochemical Exploration, 168:119-126.

Bonaventura, P., G.Benedetti, , and P. Miosse. 2015. Zinc and its role in immunity and inflammation. Autoimmunity Reviews, 14 (4): 277-285.

Boonchuay,B., I. Cakmak, B. Rerkasem, and C. Prom-U-Thai, 2013. Effect of different foliar zinc application at different growth stages on seed zinc concentration and its impact on seedling vigor in rice. Soil Science and Plant Nutrition, 59(2): 180-188.

https://doi.org/10.1080/00380768.2013.763382

Bouain, N., Z. Shahzad, A. Rouached, G.A. Khan, Berthomieu, P. and C. Abdelly, et al., 2014.Phosphate and zinc transport and signalling in plants: toward a better understanding of their homeostasis interaction. J. Exp. Bot., 65: 5725 - 5741. http://doi.org/10.1093/jxb/eru314

Bouis, H.E., and R.M. Welch, 2010. Biofortification-A sustainable agricultural strategy for reducing micronutrient malnutrition in the global south. Crop Science, 50: S20-S32.

Bradl, H.B., 2004. Adsorption of heavy metal ions on soils and soils constituents. Journal of Colloid and Interface Science 277, 1-18.

Brehler, B., and K.H. Wedepohl, 1978. Zinc. In Handbook of Geochemistry, Vol. II/3. Ed. K.H. Wedepohl, Springer-Verlag, Berlin. 125 pp.

Brennan, R.F., 2005. Zinc Application and Its Availability to Plants. Ph. D. dissertation, School of Environmental Science, Division of Science and Engineering, Murdoch University.

Broadley, M.R., P.J. White, J.P. Hammond, I. Zelko, and A. Lux, 2007. Zinc in plants. New Phytol, 173:677-702.

Broadley, M. J., et al., 2010. Shoot, zinc (Zn) concentration varies widely within Brassica oleracea L. and is affected by soil $\mathrm{Zn}$ and phosphorus (P) levels. The Journal of Horticultural Science \& Biotechnology, 85: 375-380.http://doi.org/10.1080/14620316.2010.11512683

Brown, P.K., I. Cakmak, and Q.L. Zhang, 1993. Form and function of zinc plant. In Robson A D. Kluwer (ed). Zinc in soil and plants. Dordrecht: Academic Publishers; 93-106.

Cakmak, I., 2000. Role of zinc in protecting plant cells from reactive oxygen species. New Phytol., 146:185-205.

Cakmak, I., 2002. Plant nutrition research priorities to meet human needs for food in sustainable ways. Plant Science, 247: 3-24.

Cakmak, I., and E. Hoffland, 2012. Zinc for the improvement of crop production and human health. Plant Soil, 361: 1-2. https://doi.org/10.1007/s11104-012-1504-0

Cakmak, I., and U.B. Kutman, 2017. Agronomic biofortification of cereals with zinc: a review. European Journal of Soil Science, 69: 172-180

Cakmak, I., and H. Marschner, 1986. Mechanism of phosphorus-induced zinc deficiency in cotton. I. Zinc deficiency enhanced uptake rate of phosphorus. Physiologia Plantarum, 68: 483-490.

Cakmak, I., and H. Marschner, 1987. Mechanism of phosphorus-induced zinc deficiency in cotton. III. Changes in physiological availability of zinc in plants is mail. Physiologia Plantarum, 70: 13-20.

Cakmak, I., M.J. McLaughlin, and P. White, 2017. Zinc for better crop production and human health. Plant and Soil, 411: 1-4.

Cakmak, I., B. Torun, B. Erenoğlu, et al., 1998. Morphological and physiological differences in the response of cereals to zinc deficiency. Euphytica, 100: 349-357. http://doi.org/10.1023/A:1018318005103

Cakmak, S., K.Y. Gu"lu"t, H. Marschner, and R.D. Graham, 1994. Effect of zinc and iron deficiency on phytosiderophore release in wheat genotypes differing in zinc efficiency. Journal of Plant Nutrition, 17: 1-17.

Cakmak, I., 2004. Identification and correction of widespread zinc deficiency in Turkey - A success story (A NATO-Science for Stability Project). Proceedings of the International Fertilizer Society, 552: $1-26$. 
Cakmak, I., 2008. Enrichment of cereal grains with zinc: Agronomic or genetic biofortification? Plant and Soil, 302: 1-17.

Cambrollé, J., J.M. Mancilla-Leytón, S. Muñoz-Vallés, T. Luque, and M.E. Figueroa, 2012. Zinc tolerance and accumulation in the salt-marsh shrub Halimione portulacoides. Chemosphere, 86 (9): 867-874.

Carbonell-Barrachina, A.A., A. Jugsujinda, and F. Burlo, R.D. Delaune, W.H. Jr Patrick, 2000. Arsenic chemistry in municipal sewage sludge as affected by redox potential and $\mathrm{pH}-$ - Water Research, 34 (1): 216-224.

Carneiro, F.S., K.P. Nunes,, F.R.C. Giachini, V.V. Lima, Z.N. Carneiro, et al., 2008. Activation of the ET-1/ETA Pathway Contributes to Erectile Dysfunction Associated with Mineralocorticoid Hypertension. The Journal of Sexual Medicine, 5 (12): 2793-2807.

Castillo-González, J., D. Ojeda-Barrios, A. Hernández-Rodríguez, A.C. González-Franco, L. RoblesHernández, and G. R. López-Ochoa, 2018. Zinc Metallo enzymes in Plants. Interciencia, 43: 242248.

Chaudhry, F.M. and J.F. Loneragan, 1972. Zinc absorption by wheat seedlings. I. Inhibition by hydrogen ions and micronutrient cat ions. Soil Science Society of America. Proc., 36: 327-331.

Chaudhry, F.M., J.F. Loneragan, 1970. Effect of nitrogen, copper and zinc fertilizers on the copper and zinc nutrition of wheat plants. Australian Journal of Agriculture Res., 21: 865-879.

Chen, G., X. Chen, and P.L. Yue, 2000. Electrocoagulation and electroflotation of restaurant wastewater. Journal of Environmental Engineering, 858-863.

Chen, L., J. Zhan, J. Tang, G. Chen, G. Zhao, and C. Zhang, 2019. Microstructure and texture evolution during porthole die extrusion of MgAl-Zn alloy. Journal of Materials Processing Tech., 259: 346352.

Chen, W., X. Yang, Z. He, Y. Feng, and F. Hu, 2008. Differential changes in photosynthetic capacity, $77 \mathrm{~K}$ chlorophyll fluorescence and chloroplast ultrastructure between $\mathrm{Zn}$ efficient and $\mathrm{Zn}$ inefficient rice genotypes (Oryza sativa) under low zinc stress. Physiol. Plant, 132: 89-101.

Chen, W.S., C. Liao, and K. Lin. 2017.Recovery Zinc and Manganese from Spent Battery Powder by Hydrometallurgical Route.Energy Procedia, 107: 167-174.

Chen, Y., and P. Barak, 1982. Iron nutrition of plants in calcareous soils. Adv. Agron., 35: 217-239.

Chesworth, W., 1991. Geochemistry of micronutrients, in: J.J. Mortvedt, F.R. Cox, L.M. Shuman, R.M. Welch (Eds.), Micronutrients in Agriculture, second ed., Soil Sci. Soc. Am. Inc., Madison, WI, 130 .

Clark, R.B., 1978. Differential response of maize inbreeds to Zn. Agronomy Journal., 70: 1057-1060.

Clemens, S., E.J. Kim, D. Neumann, and J.I. Schroeder, 1999. Tolerance to toxic metals by a gene family of phytochelatin synthases from plants and yeast. The EMBO journal, 18: 3325-3333.

Clemente, A.C., 2010. Assessments of waste rock weathering characteristics at the Antamina mine based on field cells experiment $(\mathrm{T})$. University of British Columbia. Retrieved from https://open.library.ubc.ca/collections/ubctheses/24/items/1.0070949

Cui, B., L. Zeng, D. Keane, M.J. Bedzyk, and D.B. Buchholz, et al., 2016.Thermal Conductivity Comparison of Indium Gallium Zinc Oxide Thin Films: Dependence on Temperature, Crystallinity, and Porosity.The Journal of Physical Chemistry, 120 (14): 7467-7475. http://doi.org/10.1021/acs.jpcc.5b12105

Cunningham, J.J., A. Fu, P.L. Mearkle, and R.G. Brown, 1994. Hyperzincuria in individuals with insulin-dependent diabetes mellitus: Concurrent zinc status and the effect of high-dose zinc supplementation. Metabolism 'Clinical \& Experimental', 43 (12): 1558-1562.

Dadlich, S., and L. Somani, 2007. Effect of integrated nutrient management in a soybean-wheat crop sequence on the yield, micronutrient uptake and post-harvest availability of micronutrients on typic ustochrepts soil. Acta Agronomica Hungarica, 55 (2): 505-516.

Dang, H., R. Li, Y.X. Sun, and Y. LI, 2010.Absorption, Accumulation and Distribution of Zinc in highly-Yielding Winter Wheat.Agricultural Sciences in China, 9: 965-973.

Darton-Hill, I., P. Webb, J.M. Hunt, N. Dalmiya, M. Chopra, M.J. Ball, et al., 2005. Micronutrient deficiencies and gender: social and economic costs. The American Journal of Clinical Nutrition, 71: 1198S-1205S.

Das, S., and A. Green, 2013. Importance of zinc in crops and human health. J SAT Agric. Res, 11:17. 
De Datta, S.K. and R.J. Buresh, 1989. Integrated nitrogen management in irrigated rice. Adv. Soil Sci., 10: $143-164$.

De Figueiredo, R.M., L. Coudray, and J. Dubois, 2007. Synthesis and biological evaluation of potential bisubstrate inhibitors of protein farnesyltransferase.Design and synthesis of functionalized imidazoles. J. organic \& Bimolecular Chemistry, 20.

De Santiago-Martín, A., I. Valverde-Asenjo, J.R. Quintana, A. Vázquez, A.L. Lafuente, C. GonzálezHuecas, , 2014. Carbonate, organic and clay fractions determine metal bioavailability in periurban calcareous agricultural soils in the Mediterranean area. Geoderma, (221-222): 103-112.

Degryse, F., V.K. Verma, and E. Smolders, 2008. Mobilization of $\mathrm{Cu}$ and $\mathrm{Zn}$ by root exudates of dicotyledonous plants in resin-buffered solutions and in soil. Plant Soil, 306: 6984.http://doi.org/10.1007/s11104-007-9449-4

Dehghanian, H., A. Halajnia, A. Lakzian, and A.R. Astaraei, 2018. The effect of earthworm and arbuscular mycorrhizal fungi on availability and chemical distribution of $\mathrm{Zn}, \mathrm{Fe}$ and $\mathrm{Mn}$ in a calcareous soil.Applied Soil Ecology, 130: 98-103.

Department of Health, 1991. Report 41. Dietary reference values for food energy and nutrients for the United Kingdom. The Stationery Office.

De-Regil, L.M., P.S. Suchdev, G.E. Vist, S. Walleser, and J.P. Peña-Rosas, 2013. Home fortification of food with multiple micronutrient powder for health and nutrition children under two years of age. Evid.-BasedChildHealth, 8:1:112-201.

Dhaliwal, S.S., H. Ram, A.K. Shukla, and G.S. Mavi, 2019. Zinc biofortification of bread wheat, triticale, and durum wheat cultivars by foliar zinc fertilization, Journal of Plant Nutrition, 42: (8): 813- 822. http://doi.org/10.1080/01904167.2019.1584218

Disante, K.B., J. Cortina, A. Vilagrosa, D. Fuentes, E.I. Hernandez, and K. Ljung 2014.Alleviation of $\mathrm{Zn}$ toxicity by low water availability. Physiologia Plantarum, 150: 412-424

Disante, K.B., D. Fuentes, and J. Cortina, 2010. Response to drought of Zn stressed Quercus suber L. Seedlings. Env. Exp. Bot., 70: 96-103.

Dobermann, A., and T. Fairhurst, 2000. Rice: Nutrient Disorders and Nutrient Management. Handbook Series, Potash \& Phosphate Institute (PPI), Potash \& Phosphate Institute of Canada (PPIC) and International Rice Research Institute, (IRRI), Singapore and Makati City, the Philippines, 191.

Drissi, S., A.A. Houssa, A. Bamouh, J.M. Coquant, and M. Benbella, 2015. Effect of zinc-phosphorus interaction on corn silage grown on sandy soil. Agriculture, 5: 1047-1059.

Ekiz, H., S. Bagci, A. Kiral, S. Eker, I. Gu"ltekin, A. Alkan, and I Cakmak, 1998. Effects of zinc fertilization and irrigation on grain yield and zinc concentration of various cereals grown in zincdeficient calcareous soils. Journal of Plant Nutrition, 21: 2245-2256.

Ellis, B.G., J.F. Davis, and W.H. Judy, 1965. Effect of method of incorporation of $\mathrm{Zn}$ in fertilizer on zinc uptake and yield of pea beans (Phaseolus vulgaris). Soil Science Society of America. Proc., 29: 635-636.

Ellis, B.G., and B.D. Knezek, 1972. Adsorption Reactions of Micronutrients in Soils. In Mortvedt, J., Giordano J. and Lindsay W.L. (ed), Micronutrient in Agriculture (pp. 59-78). Soil Science Society of America. Madison, Wis.

Emamverdian, A., Y.Ding, F. Mokhberdoran, and Y. Xie, 2015. Heavy Metal Stress and Some Mechanisms of plant defense response. The Scientific World Journal. Article ID 756120, 18 pages. http://dx.doi.org/10.1155/2015/756120

Englbrecht, C.C., H. Schoof, and S. Böhm, 2004. Conservation, diversification and expansion of $\mathrm{C}_{2} \mathrm{H}_{2}$ zinc finger proteins in the Arabidopsis thaliana genome. BMC Genomics 5, 39. https://doi.org/10.1186/1471-2164-5-39

Erenoglu E., U.B. Kutman, Y. Ceylan, B. Yildiz and I. Cakmak 2010. Improved nitrogen nutrition enhances root uptake, root-to-shoot translocation and remobilization of zinc $(65 \mathrm{Zn})$ in wheat. New Phytol., 189:438-448.

Evans, D., and M. Miller, 1988. Vesicular-arbuscular mycorrhizas and the soil-disturbance-induced reduction of nutrient absorption in maize. New Phycologist, 110: 67-74.

FAO, 2015. Food and Agriculture Organization of the United Nations, FAOSTAT, food balance sheets. Available online: http://www.faostat.org.

FAO/WHO, 2002. Human vitamin and mineral requirements - Report of a joint FAO/WHO expert consultation - Bangkok, Thailand, FAO, Rome. Chapter, Zinc, 16: 257- 270. 
Fontes, M.P.F., and L.R.F. Alleoni, 2006. Electrochemical attributes and availability of nutrients, toxic elements, and heavy metals in tropical soils.Sci. agric. (Piracicaba, Braz.) vol.63 no.6 Piracicaba Nov. / Dec. 2006.

Förstner, U., 1995. Land contamination by metals: global scope and magnitude of problem. In Metal Speciation and Contamination of Soil. Eds. H. E. Allen, C. P. Huang, G. W. Bailey and A. R. Bowers. pp. 1-33. Lewis Publishers, Boca Raton, FL.

Foster, M., and S. Samman, 2010. Zinc and Redox Signaling: Perturbations Associated with Cardiovascular Disease and Diabetes Mellitus. Antioxidants \& Redox Signaling, Volume 13, Number 10. DOI: $10.1089=$ ars.2010.3111

Fraga, C., 2005. Relevance, essentiality and toxicity of trace elements in human health.Literature Review in Molecular Aspects of Medicine 26 (4-5): 235-44. http://doi.org /10.1016 j.mam.2005.07.013

Frassinetti, S ., G. Bronzetti, L. Caltavuturo, M. Cini, C.D. Croce, 2006. The role of zinc in life: a review. Journal of Environmenal Pathology, Toxicology, and Oncology, 25: 579 - 610.

Ganeshmurthy, A.N., M. Ali and C.H. Srinivasarao, 2006. Role of pulses in sustaining soil health and crop production. Ind. J. Fret., 1: 29-40.

Gao H., et al., 2010. Telomerase recruitment in Saccharomyces cerevisiae is not dependent on Tel1mediated phosphorylation of Cdc13. Genetics 186 (4):1147-59. http://Doi:10.1534/genetics.110.122044

Gao, X., Y. Zhang, P. Arrazola, O. Hino, T. Kobayashi, R.S. Yeung, B. Ru, and D. Pan, 2002. Tsc tumour suppressor proteins antagonize amino-acid-TOR signalling. Nat. Cell Biol. 4(9): 699-704.

Gao, X., C. Zou, X. Fan, F. Zhang, and E. Hoffland, 2006. From Flooded to Aerobic Conditions in Rice Cultivation: Consequences for Zinc Uptake. Plant Soil, 280: 41-47. https://doi.org/10.1007/s11104-004-7652-0

Gibson, R.S., 2015. Dietary-induced Zinc Deficiency in low Income Countries. Challenges and Solutions. Nutrition Today, 50 (1): 49-55. http://doi.org/10.1097/NT.0000000000000070

Gibson, R.S., 2012. Zinc deficiency and human health: etiology, health consequences, and future solutions. Plant Soil, 361: 291-299. https://doi.org/10.1007/s11104-012-1209-4

Gideon, Y.B., F.B. Fatoye and J. Omada, 2014. Sedimentological characteristics and geochemistry of Ajali sandstone exposed at Ofe-Jiji and environs, Northern Anambra Basin, Nigeria. Research Journal of Environmental and Earth Sciences, 6 (1): 10-17.

Gillman, G.P., 2007. "An analytical tool for understanding the properties and behavior of variable charge soils," Soil Research, 45(2): 83-90.

Gismera, M.J., J . Lacal, P. Silva, R. Garcia, M.T. Sevilla, and J.R. Procópio, 2004 . Study of metal fractionation in river sediments: a comparison between kinetic and sequential extraction procedures. Environmental Pollution, 227: 175 - 182.

Gokak, I.B. and T.C. Taranath, 2015. Seed germination and growth responses of Macrotyloma uniflorum (Lam.) Verdc. exposed to Zinc and Zinc nanoparticles. International Journal of Environmental Sciences, 5 (4): 840-847.

Gonçalves Junior, A.C., H. Nacke, N.G. Marengoni, E.A. Carvalho, and G.F. Coelho, 2010. Produtividade e componentes de produção da soja adubada com diferentes doses de fósforo, potássio e zinco. Cienc. Agrotec, 34:660-666

Goudia B.D., and C.T. Hash, 2015. Breeding for high grain Fe and Zn levels in cereals. Int. J. Innovation Appl. Stud., 12: 342- 354.

Goudia, B.D., and C.T. Hash, 2015. Breeding for high grain Fe and Zn levels in cereals. International Journal of Innovation and Applied Studies, 12 (2): 342-354.

Graham, R.D., J.S. Ascher, and S.C. Hynes, 1992. Selecting zinc-efficient cereal genotypes for soils of low zinc status. Plant and Soil, 146: 241-250.

Graham, R.D., D. Senadhira, S. Beebe, C. Iglesias, and I. Monasterio, 1999. Breeding for micronutrient density in edible portions of staple food crops: Conventional approaches. Field Crops Research, 60: $57-80$.

Graham, R.D., M. Knez, and R.M. Welch, 2012. Chapter One - How Much Nutritional Iron Deficiency in Humans Globally Is due to an Underlying Zinc Deficiency? Advances in Agronomy, 115: 140 . 
Grewal, H.S., R.D. Graham, and Z. Rengel, 1996. Genotypic variation in zinc efficiency and resistance to crown rot disease (Fusarium graminearum Schw Group 1) in wheat. Plant Soil, 186: 219-226. 10.1007/BF02415517

Guadalix, M.E. and M.T. Pardo, 1995. Zinc sorption by acid tropical soils as affected by cultivation. J. Soil Sci., 46: 47-51.

Gupta, N., H. Ram, and B. Kumar, 2016. Mechanism of Zinc absorption in plants: uptake, transport, translocation and accumulation. Rev Environ Sci Biotechnol, 15: 89-109. http://doi.org/10.1007/s11157-016-9390-1

Hacisalihoglu, H., and L.V. Kochian, 2003. How do some plants tolerate low levels of soil zinc? Mechanisms of zinc efficiency in crop plants. New Phytologist, 159: 341-350.

Hafeez, B., M. Khanif, and M. Saleem, 2013. "Role of zinc in plant nutrition- A review" .American, journal of experimental Agriculture, 3 (2): 374-391.

Hambidge, M. and F.S. Krebs, 2001. Interrelationships of key variables of human zinc homeostasis: Relevance to dietary zinc requirements. Annual Review of Nutrition 2001 21:1, 429-452.

Hänsch, R., and R.R. Mendel, 2009. Physiological functions of mineral micronutrients $(\mathrm{Cu}, \mathrm{Zn}, \mathrm{Mn}$, $\mathrm{Fe}, \mathrm{Ni}, \mathrm{Mo}, \mathrm{B}, \mathrm{Cl}$ ). Curr. Opin. Plant Biol., 12 (3): 259-266.

He, Y., B. Men, X. Yang, Y. Li, H. Xu, and D. Wang, 2019. Relationship between heavy metals and dissolved organic matter released from sediment by bioturbation/bioirrigation. J. Env. Sci., 75, 216-223. https://doi.org/10.1016/j.jes.2018.03.031

Hegazy, M. H., F.M. Alzuaibr, A.A. Mahmoud, H.F. Mohamed, and A.H. Hussein, 2016. The Effects of Zinc Application and Cutting on Growth, Herb, Essential Oil and Flavonoids in Three Medicinal Lamiaceae Plants. European Journal of Medicinal Plant, 12(3): 1-12.

Helfenstein, J., M.L. Pawlowski, C.B. Hill, J. Stewart, D. Lagos-Kutz, C.R. Bowen, et al., 2015. Zinc deficiency alters soybean susceptibility to pathogens and pests. J. Plant Nutr. Soil Sci. 178, 896903. 10.1002/jpln.201500146.

Hiller, S., 2006. Mineralogical and chemical data. In Isims, G.M.R. and Cripps, J.C. (Ed). Clay Materials Used in Construction Company. London Geological Society, Engineering Special publication, 21: 449-459.

Hoffland, E., C. Wei, and M. Wissuwa, 2006. Organic anion exudation by lowland rice (Oryza sativa L.) at zinc and phosphorus deficiency. Plant Soil, 283:155-162.

Hotz, C., K.H. Brown, (eds), 2004. Assessment of the Risk of Zinc Deficiency in Populations and Options for its Control. Food and Nutrition Bulletin, 25 (Supplement 2): S91- S204.

Hou, D., K. Wang, T. Liu, H. Wang, Z. Lin, J. Qian, L. Lu, and S. Tian, 2017. Unique Rhizosphere Micro-characteristics Facilitate Phytoextraction of Multiple Metals in Soil by the Hyperaccumulating Plant Sedum alfredii. Environmental Science \& Technology, 51 (10): 56755684. DOI: $10.1021 /$ acs.est.6b06531

Hussain, S., M.A. Maqsood, A. Aziz, and S.M.A. Basra, 2013. Zinc bioavailability response curvature in wheat grains under incremental zinc applications. Archives of Agronomy and Soil Science, 59:7, 1001-1016, http://doi.org/10.1080/03650340.2012.701732

Impa, S.M., and S.E. Johnson-Beebout, 2012. Mitigating zinc deficiency and achieving high grain $\mathrm{Zn}$ in rice through integration of soil chemistry and plant physiology research. Plant Soil, 361: 3-41. https://doi.org/10.1007/s11104-012-1315-3

Imtiaz, M., 1993. Zn deficiency in cereals. PhD Thesis Reading University, U.K; 1999. Norvell WA, Welch RM. Growth and nutrient uptake by barley: Studies using an N (2- Hydroxyethyle) ethylenedinitrilotriacetic acid buffered nutrient solution technique. I. Zinc ion requirements. Plant Physiology, 101: 619-625.

Institute of Medicine, Food and Nutrition Board, 2001. Dietary Reference Intakes for Vitamin A, Vitamin K, Arsenic, Boron, Chromium, Copper, Iodine, Iron, Manganese, Molybdenum, Nickel, Silicon, Vanadium, and Zinc. Standing Committee on the Scientific Evaluation of Dietary Reference Intakes. Food and Nutrition Board, Institute of Medicine. National Academy Press, Washington, DC, USA.

International Plant Nutrition Institute (IPNI). http://www.ipni.net.catalog

Iratkar, A.G., J.D. Giri, M.M Kadam, J.N. Giri, and M.B. Dabhade, 2014. Distribution of DTPA extractable micronutrients and their relationship with soil properties in soil of Parsori watershed of Nagpur district of Maharashtra. AJSS, 9:297-299. 
Ivanov, Y.V., A.V. Kartashov, A.I. Ivanova, Y.V. Savochkin, and V.V. Kuznetsov, 2016. Effects of zinc on Scots pine (Pinus sylvestris L.) seedlings grown in hydroculture. Plant Physiology and Biochemistry, 102: 1-9.

Jain, A., B. Sinilal, G. Dhandapani, R.B. Meagher, and S.V. Sahi, 2013. Effects of Deficiency and Excess of Zinc on Morphophysiological Traits and Spatiotemporal Regulation of Zinc-Responsive Genes Reveal Incidence of Cross Talk between Micro- and Macronutrients, Environmental Science \& Technology, 47 (10): 5327-5335.DOI: 10.1021/es400113y

Jain, R., S. Srivastava, and S. Solomon, et al., 2010. Impact of excess zinc on growth parameters, cell division, nutrient accumulation, photosynthetic pigments and oxidative stress of sugarcane (Saccharum spp.). Acta Physiol Plant, 32: 979-986. https://doi.org/10.1007/s11738-010-0487-9

Jangir, Y., A.A. Karbelkar, N.M. Beedle, L.A. Zinke, G. Wanger, C.M. Anderson, et al., 2019. In situ Electrochemical Studies of the Terrestrial Deep Subsurface Biosphere at the Sanford Underground Research Facility, South Dakota, USA. Front. Energy Res., 01 November 2019. https://doi.org/10.3389/fenrg.2019.00121

Johnson-Beebout S. E., J. G. Lauren, and J.M. Duxbury, 2009. Immobilization of zinc fertilizer in flooded soils monitored by adapted DTPA soil test. Commun. Soil Sci. Plant Anal., 40: 1842-1861 http://doi.org/10.1080/00103620902896738

Kabata-Pendias, A., 2010. Trace Elements in Soils and Plants: Fourth Edition, CRC Press/Taylor \& Francis Group: Boca Raton, FL, USA. http:// www. crcpress.com

Kabata-Pendias, A. and H. Pendias, 1999. Biogeochemistry of Trace Elements. 2nd ed. Wyd. Nauk PWN, Warsaw, Poland, Pp 400. (in Polish).

Kabata-Pendias, A. and H. Pendias, 2001.Trace Elements in Soils and Plants. 3rd ed. Pp. 505. Taylor and Francis, Boca Raton.

Kasim, W.A., 2007. Physiological consequences of structural and ultra-structural changes induced by Zn stress in Phaseolus vulgaris. I. Growth and Photosynthetic apparatus. Int. J. Bot., 3 (1):15-22.

Katyal, I.C. and N.S. Randhawa, 1983. Micronutrients. FAO Fertilizer and Plant nutrient bulletin. pp 3-76.

Kausar, M.A., F.M. Chaudhry, and A. Rashid, et al.,1976. Micronutrient availability to cereals from calcareous soils. Plant Soil 45, 397-410 . https://doi.org/10.1007/BF00011702

Khan, M.I.R. and N.A. Khan, 2014. Ethylene reverses photosynthetic inhibition by nickel and zinc in mustard through changes in PS II activity, photosynthetic nitrogen use efficiency, and antioxidant metabolism. Protoplasma: 1007-1019. https://doi.org/10.1007/s00709-014-0610-7

Khoshgoftarmanesh A.H., M. Afyuni, M. Norouzia, S. Ghiasi, and R. Schulin, 2018.Fractionation and bioavailability of zinc ( $\mathrm{Zn}$ ) in the rhizosphere of two wheat cultivars with different $\mathrm{Zn}$ deficiency tolerance.Geoderma, 39 (1): 1-6.

Kiekens, L., 1995. Zinc, in: B.J. Alloway (Ed.), Heavy Metals in Soils, Second ed., Blackie Academic and Professional, London, 284-305.

Kihara, J., G.W. Sileshi, G. Nziguheba, M. Kinyua, S. Zingore, and R. Sommer, 2017. Application of secondary nutrients and micronutrients increases crop yields in sub-Saharan Africa. Agronomy for Sustainable Development, 37:25.

Kirk, G.J.D. and B. Bajita, 1995. Root-induced iron oxidation, p H changes and zinc solubilization In the rhizosphere of lowland rice. New phutol.131:129-137

Kirk, G.J.D. and M. Saleque, 2005. Solubilization of phosphate by rice plants growing in reduced soil: Prediction of the amount solubilized and the resultant increase in uptake. European Journal of Soil Science, 46: 247 - 255. DOI: 10.1111/j.1365-2389.1995.tb01833.x.

Kirk, G.J.D, 2004. The Biogeochemistry of Submerged Soils. John Wiley and Sons Ltd. The Atrium, Southern Gate, Chichester, West Sussex PO19 8SQ, England.

Kisko, M., N. Bouain, A. Rouached, S. Choudhary, and H. Rouached, 2015. Molecular mechanisms of phosphate and zinc signalling crosstalk in plants: Phosphate and zinc loading into root xylem in Arabidopsis. Environmental and Experimental Botany, 114: 57-64.

Klug, A., 1999. Zinc finger peptides for the regulation of gene expression. Journal of Molecular Biology, 293 (2): 215-218.

Knight, B., F. Zhao, S. McGrath, et al., 1997. Zinc and cadmium uptake by the hyperaccumulator Thlaspi caerulescens in contaminated soils and its effects on the concentration and chemical 
speciation of metals in soil solution. Plant and Soil, 197: 71-78. http://doi.org/10.1023/A:1004255323909

Kobayashi, K., A. Sakamoto, K. Kubo, Z. Rybka, K. Kanno, and H. Takatsuji, 1998. Short communication "Seven zinc-finger transcription factors are expressed sequentially during the development of anthers in petunia". The Plant Journal, 13(4): 571-576.

Krauskopf, K.B., 1972. Geochemistry of Micronutrients. In Micronutrients in Agriculture. (Eds.) Mortved J. J., Goirdano P. M. and Lindsay W. L. Soil Science Society America, Inc. Madison, Wisconsin USA.

Krebs, N.F., L.V. Miller, and K.M. Hambridge, 2014. Zinc deficiency in infants and children: a review of its complex and synergistic interactions. Paediatrics \& International Child Health, 34: 279-288.

Krezel, A. and W. Maret, 2016. The biological inorganic chemistry of zinc ions. Archives of Biochemistry \& Biophysics, 611: 3- 19.

Kumari, K., J. Prasad, I.S. Solanki, and R. Chaudhary, 2018. Long-term effect of crop residues incorporation on yield and soil physical properties under rice-wheat cropping system in calcareous soil. J. Soil Sci. Plant Nutri., 18(1): 27-40.

Küpper, H. and E. Andresen, 2016. Mechanisms of metal toxicity in plants.Metallomics, Issue, 3. DOI: 10.1039/b000000x

Küpper, H., F.J. Zhao, and S.P. McGrath, 1999. Cellular compartmentation of zinc in leaves of the hyperaccumulator Thlaspi caerulescens. Plant Physiol., 119: 305-311. Doi: 10.1104/pp.119.1.305

Lambert, D.H., D.E. Baker, and H.Jr. Cole, 1979. The role of mycorrhizae in the interactions of phosphorus with zinc, copper, and other elements. Soil Sci. Soc. Am. J., 43:976-980.

Lantican, M.A., L.P. Prabhu, and S. Rajaram, 2003. Is research on marginal lands catching up? The case of unfavourable wheat growing environments. Agricultural Economics, 29: 353-361.

Lehmann, A., S.D. Veresoglou, E.F. Leifheit, and M.C. Rillig, 2014. Arbuscular mycorrhizal influence on zinc nutrition in crop plants. A meta-analysis. Soil Biology \& Biochemistry, 69: 123-131.

Leite, C.M.C, R.C. Alinne da Silva Fábio, F.G. César, G.F. Guimarãe, A. Eduardo, and M. Takashi, 2020. Low efficiency of $\mathrm{Zn}$ uptake and translocation in plants provide poor micronutrient enrichment in rice and soybean grains, Journal of Plant Nutrition, 43(1): 7991, http://doi.org/10.1080/01904167.2019.1659341

Li, G., C. Li, Z. Rengel, H. Liu, and P. Zhao, 2020. Excess Zn-induced changes in physiological parameters and expression levels of TaZips in two wheat genotypes. Environmental and Experimental Botany, V. 177, 104133. https://doi.org/10.1016/j.envexpbot.2020.104133

Li, X., Y. Yang, L. Jia, H. Chen, and X. Wei, 2013. Zinc-induced oxidative damage, antioxidant enzyme response and proline metabolism in roots and leaves of wheat plants. Ecotoxicol. Environ. Saf., 89: $150-157$.

Lin, A. M.Y., P.L. Chen, and P.L. Chao, 2005. Antioxidative Effect of Vitamin D3 on Zinc-Induced Oxidative Stress in CNS. Ann. N.Y. Acad. Sci., 1053: 319-329. New York Academy of Sciences. http://doi.org/10.1196/annals.1344.028

Lindsay, W.L., 1972. Zinc in soils and plant nutrition. Advances in Agronomy, 24, 147-186.

Lindsay, W.L., 1979. Chemical Equilibria in Soils. Wiley, New York.

Loneragan, J.F. and M.J. Webb, 1993. Interactions between $\mathrm{Zn}$ and other Nutrients affecting the Growth of Plants. In A.D. Robson (ed). Zinc in soils and plants (p.151). Kluwer Academic Publisher, Dordecht.

Loneragan, J.F., T.S. Grove, A.D. Robson, and K. Snowball, 1979. Phosphorus toxicity as a factor in zinc phosphorus interaction. Soil Science Society of America J., 43: 966-972.

Loneragan, J.F., D. Grunes, R. Welch, E. Aduayi, A. Tengah, V. Lazar, et al., 1982. Phosphorus accumulation and toxicity in leaves in relation to zinc supply. Soil Science Society of America Journal, 46: 345-352.

Lorenz, K., M. Gonsalves, V. Kim, V. Narayanan, and S. Mahajan, 2000. Comparative study of GaN and AlN nucleation layers and their role in growth of $\mathrm{GaN}$ on sapphire by metalorganic chemical vapor deposition. Appl. Phys. Lett. 77, 3391. https://doi.org/10.1063/1.1328091

Lott, J.N., and E. Spitzer, 1980. X-ray analysis studies of elements stored in protein body globoid crystals of Triticum grains. Plant Physiology, 66: 494-499. 
Lukaski, H.C., 2004. Vitamin and mineral status: effects on physical performance. Nutrition, 20:632644.

Ma"ser, P., et al.,(2001).

Maret, W., and H.H. Sandstead, 2006.Zinc requirements and the risks and benefits of zinc supplementation. Journal of Trace Elements in Medicine and Biology, 20 (1): 3-18.

Maret, W.S., and H.H. Stead, 2006. Zinc requirements and the risks and benefits of zinc supplementation. Journal of Trace Elements in Medicine and Biology, 20: 1.

Marichali, A., S. Dallali, S. Ouerghemmi, H. Sebei, and K. Hosni, 2014.Germination, morphophysiological and biochemical responses of coriander (Coriandrum sativum L.) to zinc excess.Industrial Crops and Products, 45:248-257.

Marichali, A., S. Dallali, S. Ouerghemmi, H. Sebei, C. Hervé, and H. Karim, 2016. Responses of Nigella sativa L. to Zinc Excess: Focus on Germination, Growth, Yield and Yield Components, Lipid and Terpene Metabolism, and Total Phenolics and Antioxidant Activities. Journal of agricultural and food chemistry. 64. 10.1021/acs.jafc.6b00274.

Marschner, H., 1995. Mineral nutrition of higher plants ( $2^{\text {nd }}$ ed., p. 889). Academic Press, London.

Marschner, H., 2011. Marschner's Mineral Nutrition of Higher Plants; Academic Press, Cambridge, MA, USA.

Marschner, H., and I. Cakmak, 1989. High light intensity enhances chlorosis and necrosis in the leaves of zinc, potassium and manganese deficient bean (Physeolus vulgaris L.) plants. Journal of Plant Physiology, 134 (3):308-15. https://doi.org/10.1016/S0176-1617(89)80248-2

Marschner, H., and A. Schropp, 1977. Vergleichende Untersuchungen uber die Empfindlichkeit von 6 Unterlagensorten der Weinrebe gegenuber Phosphat induziertem Zink Mangel Vitis. Vol. 16 No. (2):79-88.

Martens, J., and E. Smolders, 2013. Zinc. In: Alloway B.J. (ed.): Heavy Metals in Soils - Trace Metals and Metalloids in Soils and their Bioavailability. Series: Environmental Pollution, 22: 465- 493. Springer, Dordrecht.

McCall, K.A., C. Huang, and C.A. Fierke, 2000. Zinc and Health: Current Status and Future Directions "Function and Mechanism of Zinc Metalloenzymes". American Society for Nutritional Sciences, 1437S-1446S.

McDonald, G.K., R.D. Graham, J. Lloyd, J. Lewis, P. Lonergan, and H. Khabas-Saberi, 2001. Breeding for improved zinc and manganese efficiency in wheat and barley. In: Rowe B (ed) $10^{\text {th }}$ Australian Agronomy Conference, Hobart

McKenna. I.M., R.L. Chaney, and F.M. Williams, 1993. The effects of cadmium and zinc interactions on the accumulation and tissue distribution of zinc and cadmium in lettuce and spinach. Environmental Pollution, 79(2): 113-12.

McMahon, M.E., R.J. Jr. Santucci, and J.R. Scully, 2019. Advanced chemical stability diagrams to predict the formation of complex zinc compounds in a chloride environment. RSC Advances, 9: 19905-19916, DOI: 10.1039/c9ra00228f

McNair, M.R., 1981. The uptake of copper by plants of Mimulus guttatus differing in genotype primarily at a single major copper tolerance Locus. New Physiolist, 88 (4): 723-730.

Memon, A.R., F.W. Memon, M. Akram, P.J. Memon, and I. Rahman, 2017. Association of Serum Zinc level with Pre Eclampsia. J. Liaquat. Uni. Med Health Sci., 16 (01):58-61, http://doi.org/10.22442/jlumhs.171610507

Mertens, J., and E. Smolders, 2013. Zinc, in: B.J. Alloway (Ed.), Heavy Metals in Soils: Trace Metals and Metalloids in Soils and Their Bioavailability, Springer, Dordrecht, Nederlands, pp. 465-493.

Michael, P.I., and M. Krishnaswamy, 2011. The effect of zinc stress combined with high irradiance stress on membrane damage and antioxidative response in bean seedlings. Environmental and Experimental Botany, 74: 171-177.

Mikkelsen, D.S. and K. Shiou, 1977. Zinc fertilization and behavior in flooded soils. Spec. Publ. No. 5 Comm. Agric. Bur., Farnham Royal. p. 59. Mineral Stresses. In A.R. Yeo and T. J. Flowers(ed). Approaches to Crop Improvement, 175-200. 
Miller, G., N. Suzuki, L. Rizhsky, A. Hegie, S. Koussevitzky, and R. Mittler, 2007. Double Mutants Deficient in Cytosolic and Thylakoid Ascorbate Peroxidase Reveal a Complex Mode of Interaction between Reactive Oxygen Species, Plant Development, and Response to Abiotic Stresses.Plant Physiol., 144: 1777-1785. DOI: https://doi.org/10.1104/pp.107.101436

Mohamed, E., et al., 2019. Zinc alpha 2 glycoprotein as an early biomarker of diabetic nephropathy in patients with type 2 diabetes mellitus. J. Bras. Nefrol., 41(4):509 - 517. http://doi.org/10.1590/2175-8239-JBN-2018-0200.

Monnet, F., N. Vaillant, V. Vernay, A. Coudre, H. Sallanon, and A. Hitmi, 2001. Relationship between PSII activity, $\mathrm{CO}_{2}$ fixation, and $\mathrm{Zn}, \mathrm{Mn}$ and $\mathrm{Mg}$ contents of Lolium perenne under zinc stress. Journal of Plant Physiology, 158 (9): 1137-1144.

Morley, J.E., 2004. The top 10 hot topics in aging. J. Gerontology, 59: 24-33.

Moussavi-Nik, M., Z. Rengel, J. Pearson, and G. Hollamby, 1997. Dynamics of nutrient remobilization from seed of wheat genotypes during imbibition, germination and early seedling growth. Plant and Soil, 197:271-280.

Mustafa, G., and S. Komatsu, 2016. Toxicity of heavy metals and metal-containing nanoparticles on plants. Biochimica et Biophysica Acta (BBA) - Proteins and Proteomics, 1864. 10.1016/j.bbapap.2016.02.020

Nanda, R. and V. Agrawal, 2016. Elucidation of zinc and copper induced oxidative stress, DNA damage and activation of defence system during seed germination in Cassia angustifolia Vahl. Environmental and Experimental Botany, 125: 31-41

Neue, H.U. and R.S. Lantin, 1994. Micronutrient Toxicities and Deficiencies in Rice in Soil Mineral Stresses. In A.R. Yeo and T.J. Flowers (ed). Approaches to Crop Improvement (pp. 175 - 200). Berlin: Springer-Verlag.

Nichols, B.A., B.G. Hopkins, V.D. Jolley, B.L. Webb, B.G. Greenwood, and G.R. Buck, 2012. Phosphorus and zinc interaction and their relationships with other nutrients in maize grown in chelator- buffered nutrient solution. Journal of Plant Nutrition, 35(1): 123 141, DOI: $10.1080 / 01904167.2012 .631672$

Norvell, W.A. and R.M. Welch, 1993. Growth and Nutrient Uptake by Barley (Hordeum vulgare 1. cvHerta): Studies Using an N-(2-Hydroxyethyl) ethylenedinitrilotri acetic Acid-Buffered Nutrient Solution Technique. 1. Zinc lon Requirements. Plant Physiol., 101: 619-625. Pages 3-18.

Noulas, C., M. Tziouvalekas, T. Karyotis, 2018. Zinc in soils, water and food crops, Invited review.Journal of Trace Elements in Medicine and Biology, 49: $252-260$.

Okoli, N., B. Uzoho, E.U. Onweremadu, U. Nkwopara and I.F. Irokwe, 2016. Zinc Fractionation of Soils of Different Parent Materials and their Relationships with Some Soil Properties. Malaysian Journal of Soil Science, 20: 49-66.

Olsen, S.R., 1972. Micronutrient Interactions. In J.M Mortved, J.J. Goirdano, and W.L. Lindsay (eds). Micronutrients in Agriculture (pp. 243-264). Soil Science Society of America, Madison, WI.

O'Sullivan, N., C.J. Asher, and F.P'C. Blarney, 1997. Nutrient disorders of sweet potato. Australian Centre for International Agricultural Research (ACIAR) Monograph, 48: 136.

Ova, E.A., U.B. Kutman, L. Ozturk, and I. Cakmak, 2015. High phosphorus supply reduced zinc concentration of wheat in native soil but not in autoclaved soil or nutrient solution. Plant and Soil, 393: $147-162$.

Peck, A.W. and G.K. McDonald, 2010. Adequate zinc nutrition alleviates the adverse effects of heat stress in bread wheat. Plant Soil, 337:355-374.

Pendias, A.K., and H. Pendias, 1992. Trace Elements in Soil and Plants ( $2^{\text {nd }}$ edition). Boca Raton, Florida: CRC Press, 365.

Peppicelli, C., P. Cleall, D. Sapsford, and M. Harbottle, 2018. Changes in metal speciation and mobility during electrokinetic treatment of industrial wastes: Implications for remediation and resource recovery. Science of The Total Environment Volume 624, 15 May 2018, Pages 1488-1503.

Pongrac, P., J.W. McNicol, and A. Lilly, et al., 2019. Mineral element composition of cabbage as affected by soil type and phosphorus and zinc fertilisation. Plant Soil, 434: 151-165. https://doi.org/10.1007/s11104-018-3628-3

Ponnamperuma, F.N., 1972. The chemistry of submerged soils. Adv. Agron., 24: 29-95.

Prasad, A. S., 1995. Zinc: an overview. Nutrition (Burbank, Los Angeles County, Calif.), 11(1 Suppl): 93-99. 
Prasad, A.S., 1998. Zinc deficiency in humans: a neglected problem physiological availability of zinc in plants is mail. Physiologia Plantarum, 70: 13-20.

Prasad, A.S., 2017. Discovery of Zinc for Human Health and Biomarkers of Zinc Deficiency. In Molecular, Genetic, and Nutritional Aspects of Major and Trace Minerals (pp. 241-260). Academic Press.

Prasad, A.S., 2009. Zinc: role in immunity, oxidative stress and chronic inflammation. Current Opinion in Clinical Nutrition and Metabolic Care, 12 (6): 646-652.

Rahimi, A., and A. Schropp, 1984. Carboanhydrase-Aktivität und extrahierbares Zink als Maßstab für die Zink- Versorgung von Pflanzen. Zeitschrift für Pflanzenernährung und Bodenkunde, 147 (5): 572-583.

Rahmatullah, I. B., and G.R. Sandhu, 1985. Fixation of zinc by some rice soil clays under upland conditions, Communications in Soil Science and Plant Analysis, 16 (6): 615620, DOI: $10.1080 / 00103628509367632$

Rao, D.E. and K.V. Chaitanya, 2016. Photosynthesis and antioxidative defense mechanisms in deciphering drought stress tolerance of crop plants. Biologiaplantarum 60:201-218, 2016. https://doi.org/10.1007/s10535-016-0584-8

Rattan, R., and D. Deb, 1981. Self-diffusion of zinc and iron in soils as affected by $\mathrm{pH}, \mathrm{CaCO}_{3}$, moisture, carrier and phosphorus levels. Plant and Soil, 63: 377-393.

Rauret, G., J.F. López-Sánchez, A. Sahuquillo, 1999. Improvement of the BCR three step sequential extraction procedure prior to the certification of new sediment and soil reference materials. Journal of Environmental Monitoring, 1:57-61.

Ray, S.K., K.K. Barman, D. Mukhopadhyay, 2018. Stability of organo-zinc complex in application of inorganic and organic nutrients to rice (Oryza sativa) growing soils of West Bengal (India). Int. J. Chem. Stud., 6:2157-2164

Reddy, M.R., and H.F. Perkin, 1974. Fixation of Zn by clay minerals. Soil Science of America. Proc., 38: 229-230.

Rehman, H., T. Aziz, M. Farooq, A. Wakeel, and Z. Rengel, 2012. Zinc nutrition in rice production systems: A review. Plant and Soil, 361: 203-226. https://doi.org/10.1007/s11104-012-1346-9

Reis, S., I. Pavia, and A. Carvalho, et al., 2018. Seed priming with iron and zinc in bread wheat: effects in germination, mitosis and grain yield. Protoplasma 255: 1179-1194. https://doi.org/10.1007/s00709-018-1222-4

Rengel, Z., 2001. Genotypic differences in micronutrient use efficiency in crops. Comm. Soil Science and Plant. Analysis, 32: 1163-1186.

Rengel, Z., 2015. Availability of Mn, Zn and Fe in the rhizosphere.Journal of Soil Science and Plant Nutrition, 201515 (2): 397-409.

Rengel, Z., G.D.Batten, D.E. Crowley, 1999. Agronomic approaches for improving the micronutrient density in edible portions of field crops. Field Crops Research, 60 (1-2): 27-40.

Robson, A., and M. Pitman, 1983. Interactions between nutrients in higher plants. In A. Läuchli \& R. L. Bieleski (Eds.), Inorganic plant nutrition (pp. 147-180).

Robson, A.A., L. Chauvaud, R.P. Wilson, and L.G. Halsey, 2012.Small actions, big costs: the behavioural energetics of a commercially important invertebrate. J. R. Soc. Interface, 9: 14861498. doi:10.1098/rsif.2011.0713

Robson, A.D., 1994. Zinc in soils and plants. Springer, New York.

Rose, T.J., C.A. Raymond, C. Bloomfield, and G.J. King, 2015. Perturbation of nutrient source-sink relationships by post-anthesis stresses results in differential accumulation of nutrients in wheat grain. J.PlantNutr.SoilSci.,178: 89-98.

Rudani, K., V. Patel, and K. Prajapati, 2018. The importance of zinc in plant growth- A review. International Research Journal of Natural and Applied Sciences, 5(2): 38-48.

Saeed, M., and R.L. Fox, 1977. Relation between suspension pH and Zn solubility in acid and calcareous soils. Soil Science, 124: 199-204.

Safaya, N.M., 1976. Phosphorus-Zinc interaction in relation rate of phosphorus, zinc, copper, manganese and iron in corn (Zea mays L.). Journal of Soil Science Society America, 71: 132-136. 
Sagardoy, R., F. Morales, R. Rellán-Álvarez, A. Abadía, J. Abadía, and A.F. López-Millán, 2011. Carboxylate metabolism in sugar beet plants grown with excess $\mathrm{Zn}$. Journal of Plant Physiology,168 (7): 730-733.

Sajwan, K.S., and W.L. Lindsay, 1988. Effect of redox, zinc fertilisation and incubation time on DTPAextractable zinc, iron and manganese. Commun. Soil Science and Plant Analysis, 19: 1-11.

Samreen, T. H., H.U. Shah, U. Saleem and M. Javid, 2017.Zinc effect on growth rate, chlorophyll, protein and mineral contents of hydroponically grown mungbeans plant (Vigna radiata). Arabian Journal of Chemistry, 10 (2): S1802-S1807.

Sarkar, A.N., and R.G. Wynjones, 1982. Effect of rhizosphere $\mathrm{pH}$ on the availability and uptake of $\mathrm{Fe}$, Mn and Zn. Plant Soil, 66: 361-372. http://doi.org/10.1007/BF02183802

Saxena, N.P., M.C. Saxena, and P. Ruckenbauer, et al., 1993. Screening techniques and sources of tolerance to salinity and mineral nutrient imbalances in cool season food legumes. Euphytica, 73: 85-93. http://doi.org/10.1007/BF00027185

Sayre, R., J.R. Beeching, E.B. Cahoon, C. Egesi, C. Fauquet, J. Fellman, M. Fregene, W. Gruissem, et al., 2011. The Bio Cassava Plus Program: biofortification of Cassava for Sub-Saharan Africa. Annu. Rev. Plant Biol., 62: 251-272.

Scheid, D., R.D. Marco, A.L. Grolli, R.F. da Silva, O. Da Ros, and R. Andreazza, 2017. Growth, tolerance and zinc accumulation in Senna multijuga and Erythrina cristagalli seedlings. Rev. Bras. Eng. Agríc. Ambient., 21 (7), Campina Grande.

Schulin, R., S. Tandy, C. Thonar, R. Grüter, F. Aghili, V. Dorostkar, et al., 2015. Zinc Biofortification of Wheat through Soil Organic Matter Management. $4^{\text {th }}$ International Zinc Symposium: Improving Crop Production and Human Health São Paulo, Brazil October 15-17, pages 42-43.

Seshadri, B., N.S. Bolan, and R. Naidu, 2015. Rhizosphere-induced heavy metal(loid) transformation in relation to bioavailability and remediation. Journal of Soil Science and Plant Nutrition15(2):524548. DOI:http://dx.doi.org/10.4067/S0718- 61495162015005000043.

Sharma, K.C., B.A. Kranz, A.L. Brown, and J. Quick, 1968. Interaction of Zn and P in Top and Root of Corn and Tomato. Agronomy Journal, 60 (5): 453-456.

Sharma, P.N., C. Chatterjee, C.P. Sharma, and S.C. Agarwala, 1987. Zinc deficiency and anther development in maize. Plant and Cell Physiology, 28(1): 11-18. https://doi.org/10.1093/oxfordjournals.pcp.a077265

Shukla, U.C. and H.D. Moris, 1967. Relative efficiency of several zinc sources for corn. Agron. J., 59: 200.

Shukla, U.C., and S.B. Mittal, 1979.Characterization of zinc application in some soils of India. Journal of Soil Science Society of America, 43: 905-908.

Shuman, L.M., 1975. The Effect of Soil Properties on Zinc Adsorption by Soils. Soil Sci. Soc. Am. J., 39(3): 454-458.

Sillanpää, M., 1982. Micronutrients and the Nutrient Status of Soils: A Global Study, FAO Soils Bulletin No. 48, 444. FAO, Rome.

Sillanpää, M., 1990. Micronutrients Assessment at the Country Level. An international Study FAO Soils Bulletin 63, Food and Agriculture Organization of the United Nations, Rome.

Sillanpää, M., and P.L.G. Vlek, 1985. Micronutrients and the agroecology of tropical and Mediterranean regions. Fert. Res, 7:151-167.

Simon, S.F., and C.G. Taylor, 2001. Dietary Zinc Supplementation Attenuates Hyperglycemia in db/db Mice. Exp Biol Med (Maywood), 226: 43-51.

Singh, B., S.K.A. Natesan, B. Singh, and K. Usha, 2005. Improving zinc efficiency of cereals under zinc deficiency. Current Science, 88: 36-44.

Singh, J.P., R.E. Karamonas, and J.W.B. Stewart, 1988. The mechanism of phosphorus-induced zinc deficiency in bean (Phaseolus vulgaris L.). Canadian Journal of Soil Science, 68:345-358.

Singh, J.P., R.E. Karamonas, and J.W.B. Stewart, 1986. Phosphorus-induced zinc deficiency in wheat on residual phosphorus plots. Agronomy Journal, 78: 668-675.

Singh, K.B., 1993. Problems and prospects of stress resistance breeding in chickpea. In: Singh, K.B. and Saxena, M.C. (eds.), Breeding for stress tolerance in cool season food legumes, pp. 17-36. John Wiley \& Sons, Chichester, UK.

Singh, M.V., and I.P. Abrol, 1986. Transformation and movement of zinc in an alkali soil and their influence on the yield and uptake of zinc by rice and wheat crops. Plant Soil, 94:445-449. 
Skoog, F., 1940. Relationships between zinc and auxin in the growth of higher plants. Am. J. Bot., 27: 939-951. http://doi.org/10.1002/j.1537-2197.1940.tb13958

Solomons, N.W., 2000. Plant-based diets are traditional in developing countries: 21st century challenges for better nutrition and health. Asia Pacific journal of clinical nutrition, 9(S1): S41-S54

Sommer, A.L., and C.B. Lipman, 1926. Evidince on the indispesale natur of zinc and boron for higher green plants. Plant Physiol., 1(3): 231-249. doi: 10.1104/pp.1.3.231

Spark, K.M., B.B. Johnson, and J.D. Wells, 1995. Characterizing heavy-metal adsorption on oxides and oxyhydroxides. European Journal of Soil Science, 46(4): 621-631.

Sposito, G., L.J. Lubd, and A.C. Chang, 1982. Trace Metal Chemistry in Arid-zone Field Soils Amended with Sewage Sludge: I. Fractionation of $\mathrm{Ni}, \mathrm{Cu}, \mathrm{Zn}, \mathrm{Cd}$, and $\mathrm{Pb}$ in Solid Phases. Soil Science Society of America Journal, 84 (3): 260-264.

Stahl, R.S., and B.R. James, 1991. Zinc sorption by B Horizons Soils as a function of pH. Journal of Soil Science Society of America, 55:1592-1597.

Stahl, R.S. and B.R. James, 1991. Zinc sorption by iron oxide coated sand as a function of pH. Soil Sci. Soc. Am. J., 55: 1287-1290.

Stein, A.J., 2010. Global impacts of human mineral malnutrition. Plant and Soil, 335:133-154.

Stein, A.J., 2014. Rethinking the measurement of under nutrition in a broader health context. Global Food Security, 3: 193- 199.

Stein, A.J., J.V. Meenakshi, M. Qaim, P. Nestel, H.P.S. Sachdev, and Z.A. Bhutta, 2005. Analyzing the Health Benefits of Biofortified Staple Crops by Means of the Disability-Adjusted Life Years Approach: a Handbook Focusing on Iron, Zinc and Vitamin A. Washington, DC: International Food, Policy Research Institute.

Streeter, T.C., Z. Rengel, S.M. Neate and R.D. Graham, 2001. Zinc fertilisation increases tolerance to Rhizoctonia solani (AG 8) in Medicago truncatula. Plant Soil, 228: 233-242. 10.doi: 10.1023/A:100487402733

Sturikova, H., O. Krystofova, D. Huska, and V. Adam, 2018. Zinc, zinc nanoparticles and plants. $J$ Hazard Mater, 349:101-110. doi:10.1016/j.jhazmat.2018.01.040

Subramanian, K.S., C. Bharathi, and A. Jegan, 2008. Response of maize to mycorrhizal colonization at varying levels of zinc and phosphorus. Biology and fertility of soils, 45: 133-144.

Subramanian, K., N. Balakrishnan, and N. Senthil, 2013. Mycorrhizal symbiosis to increase the grain micronutrient content in maize. Australian Journal of Crop Science, 7: 900.

Sylvia, D., L. Hammond, J. Bennett, J. Haas, and S. Linda, 1993. Field response of maize to a VAM fungus and water management. Agronomy Journal, 85: 193-198.

Szatanik-Kloc, A., P. Warchulska, and G Józefaciuk, 2009. Changes in variable charge and acidity of rye (Secale cereale L.) roots surface under Zn-stress. Acta Physiol. Plant., 31: 59-64.

Takkar, P.N., and N.S. Randhawa, 1978. Micronutrients in Indian Agriculture. Fertility News; 23:3-26.

Takkar, P.N., and C. Walker, 1993. The Distribution and Correction of Zinc Deficiency. In A.D. Robson (ed). Zinc in Soils and Plants (pp. 51). London: Kluwar Academic publisher,

Tandon, H.L.S., 1995. Micronutrients in soils, crops and fertilisers: a sourcebook-cum-directory pp.144.

Tavallali, V., M. Rahemi, S. Eshghi, B. Kholdebarin, and A. Ramezanian, 2010. Zinc alleviates salt stress and increases antioxidant enzyme activity in the leaves of pistachio (Pistacia veraL. 'Badami') seedlings, Turk. J. Agr. Forest, 34(4):349-359.

Teng, W., Y. Deng, X. Chen, X. Xu, R. Chen, Yang, L.V., Y. Zhao, X. Zhao, X. Bin Li, Yi. Tong, Fu. Zhang, and Z. Sheng Li, 2013. Characterization of root response to phosphorus supply from morphology to gene analysis in field-grown wheat. Journal of Experimental Botany, 64: 14031411.

Terrin, G., R.B. Canani, M. di Chiara, A. Pietravalle, V. Aleamdri, F. Conte, et al., 2015. Zinc in early life: a key element in the fetus and preterm neonate. Nutrients, 7: 10427- 10446.

Tessier, A., P.G.C. Campbell, N.M. Bisson, 1979. Sequential extraction procedure for the speciation of particulate trace metals. Analytical Chemistry, 51:844-851.

Thompson, J., T. Clewett, and M. Fiske, 2013. Field inoculation with arbuscular-mycorrhizal fungi overcomes phosphorus and zinc deficiencies of linseed (Linum usitatissimum) in a vertisol subject to long-fallow disorder. Plant and Soil, 371: 117-137. 
Tiller, K.G., J. Gerth, and G. Brümmer, 1984. The sorption of Cd, Zn and Ni by soil clay fractions: procedures for partition of bound forms and their interpretation. Geoderma, 34: 1-16.

Tisdale, S.L., W.L. Nelson, and J.D. Beaten, 1984. Zinc In soil Fertility and Fertilizers. Fourth edition, Macmillan Publishing Company, New York, 382-391.

Torri, S.I. and L. Lavado, 2008. Zinc distribution in soils amended with different kinds of sewage sludge. Journal of Environmental Management 88, 1571-1579.

Tripathi, B.N., and J.P. Gaur, 2004. Relationship between copper- and zinc-induced oxidative stress and proline accumulation in Scenedesmus sp. Planta, 219: 397-404. http://doi.org/10.1007/s00425-004-1237-2

Tsednee, M., S. Yang, D. Lee, and K. Yeh, 2014. Root-Secreted Nicotianamine from Arabidopsis halleri Facilitates Zinc Hypertolerance by Regulating Zinc Bioavailability. Plant Physiology, 166: 839-852.

Tsonko, T. and F.J.C. Lidon, 2012. Zinc in plants - An overview. Emir. J. Food Agric., 24 (4): 322-333.

Udo, E.J., L.H. Bhon, and T.C. Tukker, 1970. Zinc adsorption by calcareous Journal of Soil Science Society of America. Proc, 34: 405-407.

Uygur, V., and D. Rimmer, 2000. Reactions of zinc with iron oxide coated calcite surfaces at alkaline $\mathrm{pH}$. European Journal of Soil Science, 51: 511-516.

Van Breemen, N. and R.U. Castro, 1980. Zinc deficiency in wetland rice along a toposequence of hydromorphic soils in the Philippines. II. Cropping experiment. Plant and Soil, 57: 215-221.

Van de Mortel, J.E., L. Almar Villanueva, H. Schat, J. Kwekkeboom, S. Coughlan, P.D. Moerland, et al., 2006. Large expression differences in genes for iron and zinc homeostasis, stress response, and lignin biosynthesis distinguish roots of Arabidopsis thaliana and the related metal hyperaccumulator Thlaspi caerulescens. Plant Physiol., 142: 1127-1147.

Venkatachalam, P., N. Priyanka, K. Manikandan, I. Ganeshbabu, P. Indiraarulselvi, N. Geetha, K. Muralikrishna, R.C. Bhattacharya, M. Tiwari, N. Sharma, and V. Sahi, 2017. Enhanced plant growth promoting role of phycomolecules coated zinc oxide nano particles with $\mathrm{P}$ supplementation in cotton (Gossypium hirsutum L.). Plant Physiology and Biochemistry, 110 (1): 118-127.

Verma, T.S. and R.S. Minhas, 1987. Zinc and phosphorus interaction in a wheat-maize cropping system. Fertilizer Research, 13: 77-86, http://doi.org/10.1007/BF01049804

Verma, V.K., R.K. Setia, P.K. Sharma, S. Sing, and A. Kumar, 2005. Pedospheric Variations in Distribution of DTPA- extractable Micronutrients in Soils Developed on Different Physiographic Units in Central Parts of Punjab, India. Int. J. Agri. Biol., 7(2), 2005

Versieren, L., E. Smets, and K. De Schamphelaere, et al., 2014. Mixture toxicity of copper and zinc to barley at low level effects can be described by the Biotic Ligand Model. Plant Soil, 381: 131-142. https://doi.org/10.1007/s11104-014-2117-6

Viets, F.G., 1966. Zinc Deficiency in Soil Plant System. In A.S. Prasad, C. Charles, Thomas Springfield II (ed). Zinc Metabolism.

Viets, F.G., L.C. Boawn, and C.L. Crawford, 1957. The effect of nitrogen and types of nitrogen carrier on plant uptake indigenous and applied zinc. Journal of Soil Science Society of America, 21: 197201.

Vijayarengan, P., and G. Mahalakshmi, 2013. Zinc Toxicity in Tomato Plants. World Applied Sciences Journal, 24 (5): 649-653. DOI: 10.5829/idosi.wasj.2013.24.05.2249

Vollenweider, P., P. Bernasconi, H. Gautschi, T. Menard, B. Frey, and M.S. Günthardt-Goerg, 2011. Compartmentation of metals in foliage of Populus tremula grown on soils with mixed contamination. II. Zinc binding inside leaf cell organelles. Environmental Pollution, 159 (1): 337347.

Wang, X., X. Yang, S. Chen, Q. Li, C.Wang, Hou, et al., 2016. Zinc Oxide Nanoparticles Affect Biomass Accumulation and Photosynthesis in Arabidopsis. Front. Plant Sci., 12 January 2016 https://doi.org/10.3389/fpls.2015.01243

Wang, Y., F. Li, J. Song, et al., 2018. Stabilization of Cd-, Pb-, Cu- and $\mathrm{Zn-contaminated} \mathrm{calcareous}$ agricultural soil using red mud: a field experiment. Environ Geochem Health, 40, 21432153.https://doi.org/10.1007/s10653-018-0089-9 
Wang, Y., Y. Li, Z. Zhou, et al., 2011. Evolution of the zinc compound nanostructures in zinc acetate single-source solution. J. Nanopart Res., 13: 5193, https://doi.org/10.1007/s1 1051-011-0504-y

Wani, P.A., and M.S. Khan, 2013. Nickel Detoxification and Plant Growth Promotion by Multi Metal Resistant Plant Growth Promoting Rhizobium Species RL9. Bull Environ Contam Toxicol, 91: 117-124. http://doi.org/10.1007/s00128-013-1002-y

Warnock, R.E., 1970. Micronutrient Uptake and Mobility within Corn Plants (Zea mays L.) in Relation to Phosphorus-induced Zinc Deficiency. Soil Sci. Soc. Am. J. 34,(5): 765-769.

Watts-Williams, S.J., T.W. Turney, A.F. Patti, and T.R. Cavagnaro, 2014. Uptake of zinc and phosphorus by plants is affected by zinc fertiliser material and arbuscular mycorrhizas. Plant and Soil, 376: 165-175.

Watts-Williams, S.J., A.F. Patti, and T.R Cavagnaro, 2013. Arbuscular mycorrhizas are beneficial under both deficient and toxic soil zinc conditions. Plant and Soil, 371: 299-312.

Webb, E.C., 1992. Enzyme Nomenclature. Academic Press, San Diego, CA

Webb, M.J., and J.F. Loneragan, 1988. Effect of zinc deficiency on growth, phosphorus concentration, and phosphorus toxicity of wheat plants. Soil Science Society of America Journal, 52: 1676-1680.

Webb, M.J., and J.F. Loneragan, 1990. Zinc translocation to wheat roots and its implications for a phosphorus/zinc interaction in wheat plants, Journal of Plant Nutrition, 13:12, 14991512, http://doi.org/10.1080/01904169009364171

Wei-Hong, X., L. Huai, M. Qi-Fu, and X. Zhi-Ting, 2007. Root Exudates, Rhizosphere Zn Fractions, and $\mathrm{Zn}$ Accumulation of Ryegrass at Different Soil Zn Levels1. Pedosphere, 17: 389-396, 10.1016/S1002-0160(07)60047-2.

Weir, R.G., G.C. Cresswell, and M.R. Loebel, 1995. Plant nutrient disorders 2: Tropical Fruit and Nut Crops. Inkata Press, Melbourne.

Weir, R.G. and G.C. Cresswell, 1993. Plant Nutrient Disorders 3: Vegetable Crops, Melbourne, Australia: Inkata Press, Melbourne.

Welch, R.M. and R.D. Graham 2004. Breeding for micronutrients in staple food crops from a human nutrition perspective. J. of Exp. Bot., 55: 353-364.

Wessells, K.R., and K.H. Brown, 2012. Estimating the Global Prevalence of Zinc Deficiency: Results Based on Zinc Availability in National Food Supplies and the Prevalence of Stunting. POLS ONE, November 29, 2012 https://doi.org/10.1371/journal.pone.0050568

White, P.J., and M.R. Broadley, 2005. Biofortifying crops with essential mineral elements. Trends in Plant Science, 10: 586-593.

White, P.J., and M.R. Broadley, 2009. Biofortification of crops with seven mineral elements often lacking in human diets-Iron, zinc, copper, calcium, magnesium, selenium and iodine. New Phycologist, 182: 49-84.

White, P.J., T.S. George, P.J. Gregory, A.G. Bengough, P.D. Hallett, and B.M. McKenzie, 2013. Matching roots to their environment, Annals of Botany, 112 (2): 207222, http://doi.org/10.1093/aob/mct123

Wijesekara, N., M.B. Wheeler, and F. Chimienti, 2009. Zinc, a regulator of islet function and glucose homeostasis. https://doi.org/10.1111/j.1463-1326.2009.01110.x

World Health Organization (WHO), 2002. The World Health Report 2002. Geneva: World Health Organization

Yoshida, S., and A. Tanaka, 1969. Zinc deficiency of the rice plant in calcareous soils. Soil Science and Plant Nutrition, 15: 75-80.

Youngdahl, L., L. Svec, W. Liebhardt, and M. Teel, 1977. Changes in the zinc-65 distribution in corn root tissue with a phosphorus variable. Crop Science, 17: 66-69.

Yun, S.W. and C. Yu, 2015. Immobilization of $\mathrm{Cd}, \mathrm{Zn}$, and $\mathrm{Pb}$ from soil treated by limestone with variation of $\mathrm{pH}$ using a column test. J. Chem., 1-8.

Zahedifar, M., 2017. Sequential extraction of zinc in the soils of different land use types as influenced by wheat straw derived biochar. Journal of Geochemical Exploration, 182 (A): 22-31.

Zhang, L. and Y. Liu, 2020. Potential interventions for novel coronavirus in China: A systematic review. J Med Virol. 2:479-490.

Zhang, F., V. Romheld, and H. Marschner, 1991. Diurnal rhythm release of phytosiderophore and uptake rate of zinc in Fe-efficient wheat. Soil Science and Plant Nutrition, 37: 671-678. 
Zhang, H., W. Davison, A.M. Tye, N.M.J. Crout, and S.D. Young, 2006. Kinetics of zinc and cadmium release in freshly contaminated soils. Environmental Toxicology and Chemistry, 25 (3): 664-670.

Zhang, W., D. Liu, Y. Liu, Z. Cui, X. Chen, and C. Zou, 2016. Zinc uptake and accumulation in winter wheat relative to changes in root morphology and mycorrhizal colonization following varying phosphorus application on calcareous soil. Field Crops Research, 197: 74-82.

Zhang, Y.Q., et al., 2012. The reduction in zinc concentration of wheat grain upon increased phosphorus-fertilization and its mitigation by foliar zinc application. Plant and Soil, 361: 143-152.

Zhao, F.J., Z.G. Shen, and S.P. McGrath, 1998. Solubility of zinc and interactions between zinc and phosphorus in the hyperaccumulator Thlaspi caerulescens. Plant, Cell \& Environment, 21 (1):108 -114 .

Zhu, Z., W. Zhang, Y. Pranolo, C.Y. Cheng, 2012. Separation and recovery of copper, nickel, cobalt and zinc in chloride solutions by synergistic solvent extraction. Hydrometallurgy, (127-128): 1-7.

Zou, C., D. Qin, M. Xu, H. Shen, and B. Wang, 2001. Nitrogen, phosphorous and potassium uptake characteristics of rice and its relationship with grain yield. Journal of Nanjing Agricultural University, 25: 6-10. 